\title{
Impact of Attitude Towards Entrepreneurship Education and Role Models on Entrepreneurial Intention
}

KWAKU AMOFAH ( $\square$ ka3@alumnes.udl.cat)

Law and Business Administration, University of Lleida, Lleida, Spain, Sunyani Technical University

\section{Research}

Keywords: Theory of Planned Behaviour, Entrepreneurial intention, Students

Posted Date: December 14th, 2020

DOI: https://doi.org/10.21203/rs.3.rs-125154/v1

License: (9) (i) This work is licensed under a Creative Commons Attribution 4.0 International License. Read Full License

Version of Record: A version of this preprint was published at Journal of Innovation and Entrepreneurship on March 19th, 2022. See the published version at https://doi.org/10.1186/s13731-022-00197-5. 


\section{Abstract}

In this paper, we investigate entrepreneurial intention by applying the Theory of Planned Behavior by Ajzen (1991). We specifically examine the role of gender on entrepreneurial education and role models or parental self-employment, by carrying out a Multi-Group Analysis. We used a web-based questionnaire to collect information from 216 students at a Spanish university. Data are analysed with the help of Structural Equation Modelling (SEM) - Partial Least Square (PLS). We conducted a tripartite analysis on Complete, Male, and Female Models. Regarding the Complete and Male Models, all the primary hypotheses were accepted, compared with four for the Female Model. We recommend the institutionalization of traineeship, elective courses, conference and workshops on entrepreneurship to boost the entrepreneurial spirit of students. Though this study has confirmed the applicability of the TPB model to entrepreneurial intention, we did not find a significant relationship between Males and Females about their entrepreneurial intentions for some relationships. But this study suggests that the relationship between PSE and PBC is stronger for Males than Females Our results have implications for entrepreneurship education scholars, program evaluators, and policymakers.

\subsection{Introduction}

Entrepreneurship is an individual's ability to turn ideas into action (European Commission, 2020). The transformative power of entrepreneurship has been widely documented, but only $37 \%$ of Europeans aspire to be self-employed compared to $51 \%$ of people in the US and China respectively. The European Commission's initiative promoting entrepreneurship, as summarized in the January 2013 Entrepreneurship Action Plan aims to reignite Europe's entrepreneurial spirit by educating young people about entrepreneurship, highlighting opportunities for women and other groups, easing administrative requirements and making easier to attract investors. The European Commission (2020) professes that 'young people still struggle to find jobs but remain more in education and training'. The youth unemployment rate in Spain increased to $30.90 \%$ in February from $30.80 \%$ in January of 2020. Accordingly, a key action plan in the Spanish Strategy on Social Economy (2017-2020) revolves around the 'support for employment and entrepreneurship' (European Commission, 2020).

Over the years, researchers have established a link between entrepreneurship and economic growth and transformation (Audretsch, Horst, \& Thurik, 2009; Stoica, Roman, \& Rusu, 2020). Due to the positive outcomes associated with entrepreneurial activity, researchers and policymakers alike are motivated in the quest to acquire an in-depth knowledge of entrepreneurial intention. Thus, the relationship between university culture and student's entrepreneurial intentions needs to be examined (Liñán, Urbano, \& Guerrero, 2011).

Entrepreneurship Education (EE) may interact with other factors to generate a more appropriate environment for entrepreneurship or it may have a moderation effect on the influence of other factors (e.g., gender) on the generation of entrepreneurial behavior (Entrialgo \& Iglesias, 2016). According to Davidsson (1995), personal factors like age, gender, education, vicarious experience, and experiences of change to a variety of attributes influence conviction and entrepreneurial intentions.

Previous studies have examined student entrepreneurship and the impact of entrepreneurship courses. Universities are required to play an important role in the environment that propels entrepreneurship and boosts students to pursue career alternative. Some researchers have analysed the role played by entrepreneurship education in shaping entrepreneurial intentions of students, (Peterman \& Kennedy, 2003; Souitaris, Zerbinati, \& Al-Laham, 2007). But the role of universities as provider and enabler of an environment conducive to nurture entrepreneurial intention, leading to new venture creation, has not been studied (Trivedi, 2016). Moreover, despite the proliferation of entrepreneurship courses, literature exploring the relationship between entrepreneurship education and entrepreneurial behavior remains limited (Kraaijenbrink, Groen, and Bos (2010); Lüthje \& Franke, 2003). Furthermore, empirical studies exploring university support factors and entrepreneurship promotion among university students are limited (Walter, Auer, \& Ritter, 2006). Turker and Selcuk (2009) posited that entrepreneurship education in general and university education in particular play a major role in shaping entrepreneurial intention among students. Kraaijenbrink et al. (2010) proposed that as universities support students in diverse means, it is necessary to understand the effect of such measures and the extent to which they could impact students' entrepreneurial careers.

Previous studies have provided much needed empirical evidence about entrepreneurial intention among students from various perspectives (Zhang, Duysters, \& Cloodt, 2014;Trivedi, 2016). Some researchers argue that entrepreneurial motivation can be nurtured with specific entrepreneurship education (Souitaris et al., 2007) whereas others disagree, questioning whether teaching can propel entrepreneurial motivation (Colette, Hill, \& Leitch, 2005).

This paper uses the theory of planned behavior (TPB) proposed by Ajzen (1991) as the basic framework to understand the entrepreneurial intention of students and then modified the same by integrating Attitude Towards Entrepreneurship Education (ATEE) and Role Models or Parental Self-Employment as antecedents of TPB to understand their influence on intention. Previous studies have used and supported the effectiveness of TPB in predicting entrepreneurial intention (Krueger, Reilly, \& Carsrud, 2000; Moriano, Gorgievski, Laguna, Stephan, \& Zarafshani, 2012). 
From the foregoing, we advance some questions: What are the entrepreneurial intentions among university students? What is the relationship between PSE and ATE and PBC? What is the relationship between ATEE and ATE and PBC? To what extent do the relationships between Males and Females differ? Following Entrialgo and Iglesias (2017), we examine the indirect effect of PSE and ATEE on entrepreneurial intentions with the TPB and also analyse the role of gender in these relationships. Thus, the main objective of this study is to examine the role played by the attitude towards entrepreneurial education (ATEE) and Parental Self-Employment (PSE) in fostering entrepreneurial intention among students.

To test the validity of the model, samples were drawn from students from a university in Catalonia, Spain. According to Liñán, Urbano, and Guerrero (2011) Catalonia has a reputation for having a hard-working population, entrepreneurial spirit, and a dynamic economy.

To our best knowledge, this is a novel approach and may encourage future research in this area. A contribution of this paper is the provision of a better understanding of the role of Entrepreneurship Education and PSE and their impact on entrepreneurial intention. Moreover, the outcomes of this study could be beneficial to policymakers to understand not only the pattern of relationships among intention antecedents but also its implications for interventions and developing entrepreneurial intention. Our paper extends the studies of Trivedi (2016) by introducing Role Model or Parental Self-employment as an additional antecedent of the TPB and gender as a moderating variable.

The remainder of the paper is structured as follows. In the second part, the literature on entrepreneurial intention in line with TPB along with the university environment and support (which we operationalize as Attitude towards Entrepreneurship Education-ATEE) is outlined. The next section provides the methodology. Finally, the results of the study and their practical implications have been provided along with direction for future research and conclusion.

\subsection{Theoretical Framework And Hypothesis Development}

\subsection{Entrepreneurial Intention and the Theory of Planned Behaviour}

Bird (1988, p. 442) defined intention as 'a state of mind directing a person's attention toward a specific object (goal) or path in order to achieve something (means)'. Entrepreneurial intention is considered to be the most critical aspect for the future formation of entrepreneurial ventures (Nguyen, Do, Vu, Dang, \& Nguyen, 2019). According to Bae et al. (2014) entrepreneurial intentions are the willingness to own or venture into a business. The concept of intention and its antecedents have received immerse attention in entrepreneurship research for its importance in predicting entrepreneurial behavior.

The TPB (Ajzen, 1991, 2002) is perhaps one of the most popular models that has caught the attention of researchers in these contemporary times. Thus among the many models (e.g. Shapero \& Sokol, 1982 and Bird, 1988) used to explain entrepreneurial intentions, none have had as much impact as Ajzen's theory of planned behavior (Ajzen, 1991; Krueger et al., 2000; Liñán \& Chen, 2009). As of April 2020, the theory of planned behavior (Ajzen, 2012) has been subject to empirical analysis in more than 4,200 papers referenced in the Web of Science bibliographical database, making it one of the popular theories in the social and behavioral sciences (Bosnjak, Ajzen \& Schmidt, 2020). They further revealed that the TPB has gained enormous attention in disciplines like health sciences, environmental science, business and management, and educational research. The model explains how the cultural and social environment affects human behavior. In this study, the TPB is used as a basic framework to understand students' entrepreneurial intentions. The TPB model has often been used to study the intention to start a venture in a couple of research setting (Krueger, 1993; Trivedi, 2016) and it has proven that Ajzen's TPB was an appropriate research framework for assessing intentions in the choice of employment (Kolvereid, 1996; lakovleva \& Kolvereid, 2009). According to the TPB, human behavior is guided by three kinds of reflections, beliefs about the likely consequences of the behavior (behavioural beliefs), beliefs about the normative expectations of others (normative beliefs), and beliefs about the presence of factors that may ease or impede performance of the behavior (control beliefs) (Bosnjak, Ajzen \& Schmidt, 2020).

\subsubsection{Attitude towards Entrepreneurship (ATE)}

Ajzen (1991) conceptualized attitude as the extent to which an individual has a positive or negative evaluation of the behavior in question. The attitude towards the behavior (entrepreneurship) is an important component concerning the perception of desirability that affects entrepreneurial intention. According to Santos, Roomi, and Liñán, 2016) and Liñán et al. (2011), attitude towards entrepreneurship has a positive impact on entrepreneurial intentions.

\subsubsection{Subjective Norm (SN)}

According to Ajzen (1991), the opinion of important reference groups such as parents, spouses, friends, and relatives may also influence the behavior of a person to perform or not perform certain actions. Social norms refer to the perceived social pressure from family, friends, or significant others to perform an entrepreneurial behavior (Ajzen, 1991). Social norms tend to contribute more weakly to intention (Kolvereid \& Isaksen, 2006) for individuals with a strong internal inner locus of control (Ajzen, 2002) compared to those with a strong action orientation (Bagozzi, 1992). Some studies did not establish any significant direct correlation between subjective norms and entrepreneurial intention

Page $3 / 26$ 
(Krueger et al., 2000; Liñán \& Chen, 2009; Santos et al., 2016). Most studies have established that subjective norms favorably affect ATE and the PBC ( Entrialgo \& Iglesias, 2016; Liñán \& Chen, 2009; Liñán et al., 2011; Liñán \& Santos, 2007; Trivedi, 2017). Some empirical studies (Scherer, Adams, Carley \& Wiebe, 1989; Mathews \& Moser, 1995); Trivedi, 2016; 2017) have asserted that social norms influence attitude and perceived behavioural control and thus indirectly entrepreneurial intention.

\subsubsection{Perceived behavioral control (PBC)}

The third and most important determinant identified by Ajzen (1991) is the perceived behavioural control. PBC examines the perceived feasibility of performing behaviour and its closely related to the perception of self-efficacy (Krueger et al., 2000). PBC is the perceived easiness or difficulty of becoming an entrepreneur (Ajzen, 1991). Although some researchers have considered PBC as similar to self-efficacy, Ajzen (2002) specifies that it is a wider construct, since it encompasses and perceived controllability of the behavior. According to Santos et al. (2016) and Liñán et al. (2011), PBC has a positive impact on entrepreneurial intentions. Generally, the more favorable the attitude and subjective norm, and the greater the perceived control, the stronger should be the individual's intention to perform the behavior in question (Bosnjak, Ajzen \& Schmidt, 2020). The figure A below is a diagram illustration of the theory of planned behavior by Ajzen (2019).

\subsection{Entrepreneurship Education and Support}

Entrepreneurship education refers to education for entrepreneurial attitudes and skills (Bae et al., 2014). It consists of 'any pedagogical program or process of education for entrepreneurial attitudes and skills (Fayolle, Gailly, \& Lassas-Clerc, 2006, p. 702). The debate about whether entrepreneurship can be promoted through education or not persist because of inconsistencies in previous studies. Whilst some empirical studies have found a positive impact from entrepreneurship education (Block, Hoogerheide, \& Thurik, 2013; Souitaris et al., 2007; Walter \& Dohse, 2012), others reported a statistically insignificant or negative relationship (Oosterbeek, van Praag, \& ljsselstein, 2010; von Graevenitz, Harhoff, \& Weber, 2010).

Research shows that participation in entrepreneurship courses increase the possibilities of a career in entrepreneurship (Valliere, 2016; lakovleva \& Kolvereid, 2009; Kolvereid \& Moen, 1997). According to Upton, Sexton, and Moore (1995), 40\% of those who pursued entrepreneurship courses started their own businesses. Liñán (2008) posits that entrepreneurship education can nurture a student's attitudes and intentions, as well as the establishment of a new firm. Previous studies suggest that certain university support policies and practices can promote entrepreneurial activities among students, for example, technology transfer offices and faculty consultants (Mian, 1996); university incubators and physical resources (Mian, 1997); and university venture funds (Lerner, 2005). Entrepreneurship Education program and the entrepreneurial support provided by universities are effective ways of obtaining the requisite knowledge about entrepreneurship and motivating young people to seek an entrepreneurial career (Henderson \& Robertson, 2000; Lin \& Si, 2014). Bae et al. (2014) in their meta-analysis suggested that entrepreneurial education is positively related to entrepreneurial intentions. The impact of education and university environment on the creation of prospective entrepreneurs and the relationship between university assistance and support and the set of new businesses have gained attention in the academic circles (Trivedi 2014). Trivedi (2016) established that the university environment and support positively affect PBC. Zhang et al. (2014) found a positive correlation between entrepreneurship education and entrepreneurial intention among students. According to Urbano and Guerrero (2013), it is expedient to expand the scope of the university from the conventional or old-fashioned mode of knowledge to an entrepreneurial ecosystem leading to the concept of an entrepreneurial university.

\subsection{Role Models/Parental Self-employment}

Entrepreneurial family background refers to those people whose parent(s) or family member(s) is (are) involved in self-employment (Bae et al., 2014). According to Stephens (n.d.) parents play a major role in how their children turn out. Parents are powerful role models for children and they can influence their children's entrepreneurial intentions. Zellweger, Sieger, and Halter (2011) argued that entrepreneurship education is less probable to promote entrepreneurial intentions of students who come from an entrepreneurial family background. According to Bae et al. (2014), entrepreneurship education may be less effective on entrepreneurial intentions for students from an entrepreneurial family compared to students without an entrepreneurial family background. In fact, they failed to support the hypothesis that, the positive link between entrepreneurship education and entrepreneurial intentions will be weaker in people from an entrepreneurial family background than for those who do not come from one.

\subsection{The Role of Gender}

Most studies claim that gender plays a major role in measuring entrepreneurial and self-employment career choice intentions (Verheul, Thurik, Grilo, \& Van der Zwan, 2012). The presence of a gap between males and females in entrepreneurship has long been recognized, (de Bruin et al., 2007; Díaz-García \& Jiménez-moreno, 2010; Hughes, Jennings, Brush, Carter, \& Welter, 2012). Males have higher entrepreneurial intentions than females (Haus, Steinmetz, Isidor, \& Kabst, 2013; Hindle, Klyver, \& Jennings, 2009; Zhao, Hills, \& Seibert, 2005). Bae et al. (2014) failed to support the hypothesis that the positive link between entrepreneurial education and entrepreneurial intentions will be weaker in males than females.

From the foregoing, the following hypotheses (see Table 1) are proposed.

Page $4 / 26$ 
Hypotheses (Primary and Secondary)

\begin{tabular}{|c|c|c|}
\hline No. & Description & \\
\hline \multicolumn{3}{|c|}{ PRIMARY HYPOTHESES } \\
\hline 1 & ATE positively influences entrepreneurial intention & $\mathrm{ATE} \rightarrow \mathrm{El}$ \\
\hline 2 & PBC positively influences entrepreneurial intention & $\mathrm{PBC} \rightarrow \mathrm{El}$ \\
\hline 3 & SN positively influences entrepreneurial intention & $\mathrm{SN} \rightarrow \mathrm{El}$ \\
\hline 4 & SN positively influences ATE & $\mathrm{SN} \rightarrow \mathrm{ATE}$ \\
\hline 5 & SN positively influences perceived behavioral control & $\mathrm{SN} \rightarrow \mathrm{PBC}$ \\
\hline \multicolumn{3}{|c|}{ SECONDARY HYPOTHESES } \\
\hline 6 & ATEE positively influences ATE & ATEE $\rightarrow$ ATE \\
\hline 7 & ATEE positively influences PBC & $\mathrm{ATEE} \rightarrow \mathrm{PBC}$ \\
\hline 8 & ATEE is positively related to entrepreneurial intention. & $\mathrm{ATEE} \rightarrow \mathrm{El}$ \\
\hline 9 & PSE positively influences ATE & $\mathrm{PSE} \rightarrow \mathrm{ATE}$ \\
\hline 10 & PSE positively influences PBC & $\mathrm{PSE} \rightarrow \mathrm{PBC}$ \\
\hline 11 & PSE are positively related to entrepreneurial intentions. & $\mathrm{PSE} \rightarrow \mathrm{El}$ \\
\hline 12 & The relationship between PSE and ATE is stronger for Males than for Females & \\
\hline 13 & The relationship between PSE and PBC is stronger for Males than for Females & \\
\hline 14 & The relationship between ATEE and ATE is stronger for Males than for Females & \\
\hline 15 & The relationship between ATEE and PBC is stronger for Males than for Females & \\
\hline
\end{tabular}

\subsection{Methodology}

The empirical analysis of this survey was carried out among university students in a Spanish university in the Catalonia region. Thus, the study is developed in a single country, a single institution, and a single culture. We used a structured on-line questionnaire. Convenience sampling technique was used because it is a popular tool in entrepreneurship research (Kolvereid, 1996; Krueger et al., 2000; Fayolle and Gailly 2005). Also, a study by Bosma, Jones, Autio and Levie (2008) established that young graduates (25-34 years) display the highest entrepreneurial propensity. We applied the SEM-PLS technique to examine the constructs of the paper and the relationship among them.

\subsection{Sample size}

We used a sample size of 216 because according to Hoyle (1995), 100 to 200 respondents is usually a good starting point in conducting path modelling. Also, Partial Least Squares (PLS) is suitable when exploratory studies are conducted and relatively small samples are used (Sánchez-Franco \& Roldán, 2005).

\subsection{Measurement Variables}

The questionnaire was divided into the following sections: demographic, independent (ATE, SN, and PBC), dependents variables (entrepreneurial intention), and Attitude towards Entrepreneurship Education and Parental Self-employment. The study adopted the Entrepreneurial Intention Questionnaire (EIQ) proposed by Liñán and Chen (2009) to measure ATE, PBC, and SNs. Variables were tested using a five-point Likert scale from 'Strongly Agree' to Strongly Disagree. Attitude towards Entrepreneurship Education/University environment and support scale originally developed by Kraaijenbrink et al. (2009) and revised by Trivedi (2016) was also used in this study. Eighteen items make up the ATEE Scale and are classified into two categories; General Education Support (check items 38-44 on Appendix) and Targeted Cognitive and Non-cognitive Support (check items 27-37 on Appendix). ATE, SN, PBC, and ATEE constructs were measured through reflective indicators. The other constructs were measured by nominal scales due to their qualitative nature: Parental Self-employed (PSE) and gender. For PSE, we asked the respondents if their mothers or fathers were entrepreneurs. It was a binary YES/NO variable. Regarding Role Models, we asked the students if, at least, one of their parents was an entrepreneur. It was a binary Yes/No variable.

\subsection{Data Analysis}


Structural equation modeling (SEM) was used to test the proposed model which hypothesizes a relationship between entrepreneurial intention, ATE, SN, PBC, and ATEE. Hypotheses H12 to H15 were tested using Multi-Group Analysis (MGA).

\subsection{Results}

\subsection{Profile of Respondents}

The number of respondents was 216, out of which 110 (50.9\%) were males and 106 (49.1\%) were females. Regarding Parental Selfemployment, 110 (50.9\%) of the respondents' parents were business owners whereas 106 (49.1\%) whereas 110 (50.9\%) reported on the contrary. About $97.4 \%$ of the respondents were undergraduate students, $88.2 \%$ of whom were not in employment. The majority of the students fall within 20-24 ages (71.8\%) category.

\subsection{PLS-SEM Results}

In this section, we present the results of the PLS-SEM analysis. According to Hair et al. (2010), a two-dimensional method can be applied for structural equation modelling (SEM); first, a measurement model analysis and second, a structural model analysis. This two-step process guarantees scale validity and reliability.

\subsubsection{Measurement Model Assessment}

According to Roldán and Sanchez-Franco (2012), the first stage of the measurement model assessment consists of observing the indicator loading values of the model (in our case, the three models: Complete, Male, and the Female). Table 2 depicts the parameters. It can be seen that Composite reliability, Cronbach's alpha, and Average Variance Extracted (AVE) exceed 0.7, 0.7, and 0.5, respectively, hence meeting the recommended values in literature (Fornell \& Larcker, 1981). Though reliability analysis may be conducted using item loadings of above 0.707 , Sánchez-Franco \& Roldán, (2005) opined that for newly developed measures, a lower threshold of 0.6 may be accepted. Generally, the measurement model of this study was investigated following four criteria's, i.e. (a) Item reliability, (b) Internal consistency, (c) Convergent validity, and (d) Discriminant validity. As shown in Table 2, almost all the values support the convergent validity of the composite scales for the Male and Female models, but fully for the Complete model. Prior to this, the analysis of the measurement model for the full sample found low loadings (check Appendix) for some items and were removed, and the PLS algorithm was run again. Scores regarding item reliability, construct reliability and convergent, and discriminant validity is satisfactory (see Tables 2 and 4). 
Table 2

Full-sample measurement model (reliability indicators)/Composites and Measures

\begin{tabular}{|c|c|c|c|c|c|c|c|c|c|c|c|c|}
\hline \multirow[t]{2}{*}{ Items } & \multicolumn{3}{|l|}{ Loadings } & \multicolumn{3}{|c|}{ Composite Reliability } & \multicolumn{3}{|l|}{ AVE } & \multicolumn{3}{|c|}{ Cronbach's Alpha } \\
\hline & Complete & M & $F$ & Complete & M & $F$ & Complete & $M$ & $F$ & Complete & $M$ & $F$ \\
\hline ATE & & & & 0.928 & 0.913 & 0.933 & 0.764 & 0.724 & 0.779 & 0.874 & 0.872 & 0.905 \\
\hline ATE2 & 0.892 & 0.833 & 0.918 & & & & & & & & & \\
\hline ATE3 & 0.850 & 0.793 & 0.882 & & & & & & & & & \\
\hline ATE4 & 0.859 & 0.917 & 0.813 & & & & & & & & & \\
\hline ATE5 & 0.895 & 0.854 & 0.913 & & & & & & & & & \\
\hline EI & & & & 0.940 & 0.936 & 0.933 & 0.724 & 0.710 & 0.703 & 0.922 & 0.917 & 0.912 \\
\hline El 1 & 0.716 & 0.784 & 0.613 & & & & & & & & & \\
\hline El 2 & 0.871 & 0.847 & 0.878 & & & & & & & & & \\
\hline EI 3 & 0.912 & 0.895 & 0.926 & & & & & & & & & \\
\hline El 4 & 0.893 & 0.898 & 0.873 & & & & & & & & & \\
\hline EI 5 & 0.810 & 0.728 & 0.845 & & & & & & & & & \\
\hline El 6 & 0.886 & 0.889 & 0.858 & & & & & & & & & \\
\hline PSE & 1.000 & 1.000 & 1.000 & 1.000 & 1.000 & 1.000 & 1.000 & 1.000 & 1.000 & 1.000 & 1.000 & 1.000 \\
\hline PBC & & & & 0.895 & 0.873 & 0.909 & 0.588 & 0.538 & 0.626 & 0.859 & 0.824 & 0.880 \\
\hline PBC 1 & 0.735 & 0.650 & 0.792 & & & & & & & & & \\
\hline PBC 2 & 0.832 & 0.847 & 0.805 & & & & & & & & & \\
\hline PBC 3 & 0.847 & 0.835 & 0.841 & & & & & & & & & \\
\hline PBC 4 & 0.709 & 0.638 & 0.784 & & & & & & & & & \\
\hline PBC 5 & 0.740 & 0.673 & 0.775 & & & & & & & & & \\
\hline PBC 6 & 0.729 & 0.729 & 0.747 & & & & & & & & & \\
\hline SN & & & & 0.914 & 0.931 & 0.882 & 0.780 & 0.817 & 0.714 & 0.859 & 0.888 & 0.801 \\
\hline SN 1 & 0.866 & 0.878 & 0.845 & & & & & & & & & \\
\hline SN 2 & 0.888 & 0.924 & 0.802 & & & & & & & & & \\
\hline SN 3 & 0.896 & 0.909 & 0.886 & & & & & & & & & \\
\hline ATEE & & & & 0.944 & 0.935 & 0.953 & 0.607 & 0.568 & 0.672 & 0.936 & 0.926 & 0.948 \\
\hline ATEE1 & 0.838 & 0.826 & 0.830 & & & & & & & & & \\
\hline ATEE2 & 0.824 & 0.737 & 0.900 & & & & & & & & & \\
\hline ATEE3 & 0.863 & 0.800 & 0.923 & & & & & & & & & \\
\hline ATEE5 & 0.799 & 0.803 & 0.825 & & & & & & & & & \\
\hline ATEE6 & 0.833 & 0.882 & 0.832 & & & & & & & & & \\
\hline ATEE7 & 0.715 & 0.765 & 0.754 & & & & & & & & & \\
\hline ATEE8 & 0.763 & 0.715 & 0.774 & & & & & & & & & \\
\hline ATEE9 & 0.674 & 0.626 & 0.715 & & & & & & & & & \\
\hline ATEE11 & 0.680 & 0.635 & 0.673 & & & & & & & & & \\
\hline ATEE12 & 0.787 & 0.749 & 0.845 & & & & & & & & & \\
\hline ATEE18 & 0.772 & 0.709 & 0.806 & & & & & & & & & \\
\hline
\end{tabular}




\subsubsection{Explanation of target endogenous variable variance}

The coefficient of determination $R^{2}$ is 0.712 for the El endogenous latent variable for the Complete model. This implies that the three latent variables (ATE and PBC) explain 71.2\% of the variance in El as shown in Table 3. The coefficient of determination for Males and Females is also shown in Table 3. According to Höck and Ringle (2006) results above the cutoffs $0.67,0.33$, and 0.19 are 'substantial', 'moderate', and 'weak' respectively. Thus the results for the three models are 'substantial'. These findings are consistent with the study by (Trivedi, 2016) who found $69 \%$ of the variance in the explanation of entrepreneurial intention.

\begin{tabular}{|llcc|}
\hline \multicolumn{2}{|l|}{ Table 3: R Square } & & \\
\hline & Complete & Male & Female \\
\hline ATE & 0.278 & 0.274 & 0.273 \\
\hline EI & 0.712 & 0.723 & 0.683 \\
\hline PBC & 0.310 & 0.384 & 0.231 \\
\hline
\end{tabular}

\begin{tabular}{|c|c|c|c|c|c|c|}
\hline \multicolumn{7}{|c|}{ Table 4: Discriminant Validity (COMPLETE) } \\
\hline & ATE & ATEE & $\mathrm{El}$ & PBC & PSE & SN \\
\hline ATE & 0.874 & & & & & \\
\hline ATEE & 0.109 & 0.779 & & & & \\
\hline $\mathrm{EI}$ & 0.791 & 0.36 & 0.851 & & & \\
\hline PBC & 0.517 & 0.188 & 0.615 & 0.767 & & \\
\hline PSE & -0.137 & -0.125 & -0.189 & $-0 . .337$ & 1.000 & \\
\hline SN & 0.525 & 0.306 & 0.620 & 0.514 & -0.295 & 0.883 \\
\hline \multicolumn{7}{|c|}{ FEMALE } \\
\hline & ATE & ATEE & $\mathrm{El}$ & PBC & PSE & SN \\
\hline ATE & 0.882 & & & & & \\
\hline ATEE & 0.120 & 0.810 & & & & \\
\hline El & 0.799 & 0.155 & 0.838 & & & \\
\hline PBC & 0.480 & 0.108 & 0.535 & 0.791 & & \\
\hline PSE & -0.086 & 0.049 & -0.142 & $-0 . .347$ & 1.000 & \\
\hline SN & 0.522 & 0.271 & 0.546 & 0.390 & -0.208 & 0.845 \\
\hline \multicolumn{7}{|c|}{ MALE } \\
\hline & ATE & ATEE & $\mathrm{El}$ & PBC & PSE & SN \\
\hline ATE & 0.851 & & & & & \\
\hline ATEE & 0.114 & 0.753 & & & & \\
\hline El & 0.767 & 0.127 & 0.842 & & & \\
\hline PBC & 0.521 & 0.294 & 0.668 & 0.734 & & \\
\hline PSE & -0.122 & -0.275 & -0.163 & $-0 . .289$ & 1.000 & \\
\hline SN & 0.518 & 0.367 & 0.663 & 0.604 & -0.276 & 0.904 \\
\hline
\end{tabular}

\subsubsection{Structural model analysis}

Using a two-tailed t-test with a significance level of $5 \%$, the path coefficient is significant if the T-statistics is larger than 1.96 . Regarding the Complete model, it can be observed that three out of the nine relationships are not significant as depicted in Table 6 . For the Male model, five of the hypotheses are accepted and four are rejected (see Table 8). Whereas, four of the hypotheses associated with the Females are accepted and five rejected as depicted in Table 7.

Figure 5 shows the variance explained (R Square) in the dependent constructs and the path coefficients (b) for the complete model. Consistent with Chin (1998), bootstrapping (5000 re-samples) was used to generate standard errors and T-statistics. Bootstrap represents a non-parametric 
approach for estimating the accuracy of PLS estimation. This helps in the assessment of the statistical significance of the path coefficients. The Complete model, Male model, and Female model explain $71.2 \%, 72.3 \%$, and $68.3 \%$ respectively of the variance in entrepreneurial intention based on SN, ATE, and PBC. These results are encouraging since most previous research typically explains less than $40 \%$.

\subsubsection{Collinearity Assessment}

Collinearity is a potential issue in the structural model and that variance inflation factor (VIF) value of 5 or above typically indicates such a problem (Hair et al., 2011). The collinearity assessment results for the Combined Model are summarized in Tables 5 . It can be observed that all VIF values are lower than 5 , signifying that there is no indicative collinearity between each set of predictor variables. 
Table 5

Outer VIF Values

\begin{tabular}{|c|c|}
\hline Items & VIF \\
\hline ATE2 & 2.898 \\
\hline ATE3 & 2.198 \\
\hline ATE4 & 2.358 \\
\hline ATE5 & 2.841 \\
\hline El 1 & 1.689 \\
\hline EI 2 & 3.170 \\
\hline EI 3 & 4.258 \\
\hline El 4 & 3.508 \\
\hline El 5 & 2.410 \\
\hline El 6 & 3.610 \\
\hline PSE & 1.000 \\
\hline PBC 1 & 1.840 \\
\hline PBC 2 & 2.595 \\
\hline PBC 3 & 2.504 \\
\hline PBC 4 & 1.773 \\
\hline PBC 5 & 2.108 \\
\hline PBC 6 & 1,665 \\
\hline SN 1 & 1.889 \\
\hline SN 2 & 2.338 \\
\hline SN 3 & 2.608 \\
\hline ATEE1 & 3.597 \\
\hline ATEE2 & 4.051 \\
\hline ATEE3 & 4.705 \\
\hline ATEE5 & 2.817 \\
\hline ATEE6 & 3.724 \\
\hline ATEE7 & 2.154 \\
\hline ATEE8 & 2.124 \\
\hline ATEE9 & 2.368 \\
\hline ATEE11 & 2.189 \\
\hline ATEE12 & 2.793 \\
\hline ATEE18 & 2.325 \\
\hline
\end{tabular}


Table 6

(COMPLETE): Structural Model Results

\begin{tabular}{|c|c|c|c|c|c|c|}
\hline Construct & (0) & (M) & STDEV & T Statistics & P Values & HYPOTHESIS \\
\hline ATE -> El & 0.559 & 0.559 & 0.059 & 9.497 & 0.000 & ACCEPT \\
\hline ATEE-> ATE & -0.077 & -0.060 & 0.116 & 0.662 & 0.508 & REJECT \\
\hline ATEE-> PBC & 0.026 & 0.043 & 0.128 & 0.200 & 0.841 & REJECT \\
\hline PBC -> El & 0.219 & 0.220 & 0.073 & 2.991 & 0.003 & ACCEPT \\
\hline PSE -> ATE & -0.024 & -0.023 & 0.084 & 0.287 & 0.774 & REJECT \\
\hline PSE -> PBC & -0.228 & -0.218 & 0.084 & 2.699 & 0.007 & ACCEPT \\
\hline SN $->$ ATE & 0.551 & 0.543 & 0.084 & 6.594 & 0.000 & ACCEPT \\
\hline $\mathrm{SN}$-> El & 0.210 & 0.210 & 0.068 & 3.103 & 0.002 & ACCEPT \\
\hline SN -> PBC & 0.423 & 0.423 & 0.092 & 4.589 & 0.000 & ACCEPT \\
\hline
\end{tabular}

Table 7

FEMALE: Structural Model Results

\begin{tabular}{|lllllll|}
\hline Construct & $\mathbf{( O )}$ & $\mathbf{( M )}$ & STDEV & T Statistics & P Values & HYPOTHESIS \\
\hline ATE -> EI & 0.610 & 0.605 & 0.087 & 7.045 & 0.000 & ACCEPT \\
\hline ATEE-> ATE & -0.077 & -0.044 & 0.163 & 0.473 & 0.636 & REJECT \\
\hline ATEE-> PBC & 0.108 & 0.059 & 0.254 & 0.424 & 0.672 & REJECT \\
\hline PBC - > El & 0.199 & 0.194 & 0.126 & 1.581 & 0.114 & REJECT \\
\hline PSE -> ATE & -0.034 & -0.042 & 0.127 & 0.270 & 0.787 & REJECT \\
\hline PSE -> PBC & -0.285 & -0.258 & 0.121 & 2.359 & 0.018 & ACCEPT \\
\hline SN -> ATE & 0.517 & 0.502 & 0.124 & 4.171 & 0.000 & ACCEPT \\
\hline SN -> El & 0.141 & 0.154 & 0.094 & 1.500 & 0.134 & REJECT \\
\hline SN -> PBC & 0.305 & 0.327 & 0.140 & 2.182 & 0.029 & ACCEPT \\
\hline Original Sample (0), Sample Mean (M), Standard Deviation (STDEV) & \\
\hline
\end{tabular}

Table 8

MALE: Structural Model Results

\begin{tabular}{|lllllll|}
\hline Construct & $\mathbf{( O )}$ & $\mathbf{( M )}$ & $\mathbf{S T D E V}$ & T Statistics & P Values & HYPOTHESIS \\
\hline ATE -> EI & 0.511 & 0.513 & 0.088 & 5.825 & 0.000 & ACCEPT \\
\hline ATEE-> ATE & -0.077 & -0.040 & 0.154 & 0.502 & 0.615 & REJECT \\
\hline ATEE-> PBC & 0.061 & 0.097 & 0.145 & 0.420 & 0.675 & REJECT \\
\hline PBC -> EI & 0.249 & 0.258 & 0.105 & 2.378 & 0.017 & ACCEPT \\
\hline PSE - ATE & 0.028 & 0.043 & 0.131 & 0.213 & 0.831 & REJECT \\
\hline PSE -> PBC & -0.154 & -0.143 & 0.130 & 1.185 & 0.236 & REJECT \\
\hline SN -> ATE & 0.588 & 0.569 & 0.132 & 4.446 & 0.000 & ACCEPT \\
\hline SN -> El & 0.247 & 0.235 & 0.114 & 2.175 & 0.030 & ACCEPT \\
\hline SN -> PBC & 0.507 & 0.492 & 0.125 & 4.059 & 0.000 & ACCEPT \\
\hline Original Sample (0), Sample Mean (M), Standard Deviation (STDEV) & \\
\hline
\end{tabular}

\subsection{Measurement Invariance of Composite Models (MICOM)}


Measurement Invariance of Composite Models (MICOM) is a logically necessary step before conducting MGA. Hult et al. (2008, p. 1028) posit that: 'failure to establish data equivalence is a potential source of measurement error (i.e., discrepancies of what is intended to be measured and what is actually measured), which accentuates the precision of estimators, reduces the power of statistical tests of hypothesis, and provides misleading results'.

The MICOM procedure provides the method for studying the invariance before the multi-group analysis. After confirming the existence of invariance, the next is to apply the MGA, comparing the explained variance of each group. MICOM involves a three-step process:

a) Configural invariance,

b) Compositional invariance and

c) Scalar invariance (equality of composite means and variances).

According to Garson (2016), running MICOM in SmartPLS normally automatically establishes configural invariance. Thus, since statistical output does not apply to the first step, we did not show it. However, steps 2 and 3 are discussed below. It must be noted that in running the MICOM, outer loadings that were insignificant were deleted. This accounts for the difference in the Algorithm figure for the MGA.

\subsubsection{Compositional invariance}

Compositional invariance is a test of the invariance of indicator weights for measurement (outer) paths between groups (Garson, 2016). According to Henseler, Ringle and Sarstedt (2016), if the results of MICOM's Steps 1 and 2 (but not step 3) show that there is lack of measurement invariance, partial measurement has been established. This result allows for the comparison of the standardized path coefficients across the groups by performing a multi-group analysis. If the analysis and tests on different required levels do not support full measurement invariance, applied research typically focusses on the least partial fulfillment of measurement invariance (Hair et al., 2010). A result of non-significance means that compositional invariance may be assumed. This implies the correlations are not significantly lower than 1.0, as depicted in Table 9. Compositional invariance has been fulfilled because the Original Correlation is equal or greater than $5 \%$ quantile.

Table 9

MICOM Step 2

\begin{tabular}{|lllll|}
\hline Items & Original Correlation & Correlation Permutation Mean & $\mathbf{5 . 0 \%}$ & Permutation p-Values \\
\hline ATE & 0.999 & 1.000 & 0.999 & 0.190 \\
\hline ATEE & 0.981 & 0.956 & 0.820 & 0.371 \\
\hline EI & 1.000 & 1.000 & 0.999 & 0.635 \\
\hline PBC & 1.000 & 0.999 & 0.996 & 0.841 \\
\hline PSE & 1.000 & 1.000 & 1.000 & 0.506 \\
\hline SN & 0.999 & 0.999 & 0.996 & 0.396 \\
\hline
\end{tabular}

\subsubsection{Scalar invariance (equality of composite means and variances)}

Following Henseler, Ringle and Sarstedt (2016), we tested for scalar invariance in a way comparable to that explained in Step 2. Permutation pvalue tests for Male and Female differences in means and variances for each of the inner model constructs. As shown in Table 10, the permutations $p$-values for Mean Original Difference are significant. However, the permutations $p$-values for the Variance original difference are all non-significant. From the forgoing, we can assume Partial invariance. 
Table 10

MICOM Step 3

\begin{tabular}{|c|c|c|c|c|c|c|c|c|c|c|}
\hline Items & $\begin{array}{l}\text { Mean - } \\
\text { Original } \\
\text { Difference } \\
\text { (MALE - } \\
\text { FEMALE) }\end{array}$ & $\begin{array}{l}\text { Mean - } \\
\text { Permutation } \\
\text { Mean } \\
\text { Difference } \\
\text { (MALE - } \\
\text { FEMALE) }\end{array}$ & $2.5 \%$ & $97.5 \%$ & $\begin{array}{l}\text { Permutation } \\
\text { p-Values }\end{array}$ & $\begin{array}{l}\text { Variance - } \\
\text { Original } \\
\text { Difference } \\
\text { (MALE - } \\
\text { FEMALE) }\end{array}$ & $\begin{array}{l}\text { Variance - } \\
\text { Permutation } \\
\text { Mean } \\
\text { Difference } \\
\text { (MALE - } \\
\text { FEMALE) }\end{array}$ & $2.5 \%$ & $97.5 \%$ & $\begin{array}{l}\text { Permutation } \\
\text { p-Values }\end{array}$ \\
\hline ATE & 0.468 & -0.004 & -0.274 & 0.265 & 0.001 & -0.286 & 0.005 & -0.389 & 0.396 & 0.160 \\
\hline ATEE & 0.171 & -0.001 & -0.266 & 0.266 & 0.218 & -0.184 & 0.001 & -0.437 & 0.434 & 0.415 \\
\hline El & 0.604 & -0.005 & -0.276 & 0.263 & & -0.029 & 0.005 & -0.361 & 0.362 & 0.879 \\
\hline PBC & 0.434 & -0.002 & -0.269 & 0.266 & 0.002 & 0.025 & 0.005 & -0.393 & 0.403 & 0.906 \\
\hline PSE & -0.296 & 0.002 & -0.259 & 0.260 & 0.036 & -0.010 & 0.000 & -0.008 & 0.011 & 0.055 \\
\hline SN & 0.322 & -0.001 & -0.279 & 0.267 & 0.019 & 0.261 & 0.000 & -0.364 & 0.367 & 0.162 \\
\hline
\end{tabular}

\subsubsection{Multi-Group Analysis (MGA)}

Having established configural and compositional invariance in Steps 1 and 2, we could compare the path coefficients of Males and Females using a multi-group analysis. The multi-group analysis uses independent samples t-tests to compare paths between groups (Kiel et al., 2000). In this study, we considered Gender as a moderator (dummy variable). This process divides the sample into two groups: males (110) and females (106). This section presents the results of the MGA for the two groups (Males and Females). According to Becker, Rai, Ringle, and Völckner (2013) researchers who failed to consider this potential issue may draw incorrect conclusions.

We start by first running the PLS Algorithm to determine whether the results for the group's specific model estimation differ. Using the 'Use Relative Values', stronger path relationships have thicker lines and smaller path coefficients have thinner lines. As shown in the diagram below, we can apply this representation to compare the results for Males and Females. From the figure, we can see that the group specific PLS coefficients differ (e.g., ATE-EI, SN-ATE, PBC-EI). Since there are differences in the group specific PLS path model estimations, we need to find out if these differences are significant by running the PLS-MGA.

Figures 7, 8 and 9 show the absolute values, outer loadings, path coefficients, and the R Square values of Males and Females. The MGA report provides path coefficients separately for the Male and Female groups, along with bootstrap-estimated standard deviations, t-values, and significance p-values as well as confidence intervals. From Figs. 7, 8 and 9, we can see differences in the regression weights or beta coefficients. However, to ascertain whether the differences are significant we have to apply the bootstrap t-test in the output section on the confidence intervals. From Table 12, it can be seen that the path from ATE - EI, SN - ATE, and SN - PBC confidence intervals overlap. This implies that at the 0.05 significance level, there is no difference in path coefficients between Male and Female samples. Thus, the paths in the structural model (ATE-EI, SN-ATE, and SN-PBC) are significant for both Males and Females, as depicted in the p-Values columns. However, for the MGA, we focus on Hypotheses H12, H13, H14, and H15. From Table 11, it can be noted that there is significant relationship between PSE and PBC but no significant relationship between the other variables; hence hypotheses $\mathrm{H} 13$ is accepted but $\mathrm{H} 12, \mathrm{H} 14$ and $\mathrm{H} 15$ are rejected. These results are confirmed by the output from the Parametric Test in Table 12, the Welch-Satterthwait Test in Table 13, the Bootstrapping Results on Table 14, and the Confidence intervals in Table 15.

According to $\mathrm{H} 12$, the relationship between PSE and ATE is stronger for men than women. However, there are no significant relationships between both groups, hence this hypothesis is rejected. According to $\mathrm{H} 13$, the relationship between PSE and PBC is stronger for men than women, hence this hypothesis is accepted. According to H14, 'The relationship between ATEE and ATE is stronger for Males than for Females'. From Table 14, it can be seen that the relationship is not significant for both groups, hence we reject this hypothesis. Regarding $\mathrm{H} 15$, the relationship between ATEE and PBC is stronger for Males than Females. However, results reveal that the relationship between the Male and Female groups was insignificant. Hence we reject this hypothesis. 


\begin{tabular}{|llll|}
\hline Items & Path Coefficients-diff (MALE - FEMALE) & p-Value original 1-tailed (MALE vs FEMALE) & p-Value new (MALE vs FEMALE) \\
\hline ATE $->$ EI & -0.156 & 0.947 & 0.105 \\
\hline ATEE -> ATE & -0.081 & 0.668 & 0.664 \\
\hline ATEE $->$ PBC & -0.048 & 0.651 & 0.697 \\
\hline PBC $->$ EI & 0.116 & 0.131 & 0.263 \\
\hline PSE $->$ ATE & -0.011 & 0.537 & 0.927 \\
\hline PSE $->$ PBC & 0.240 & 0.022 & 0.043 \\
\hline SN_-> ATE & -0.023 & 0.564 & 0.872 \\
\hline SN_- EI & 0.083 & 0.191 & 0.382 \\
\hline SN_- PBC & 0.189 & 0.063 & 0.126 \\
\hline
\end{tabular}

Table 12

Parametric Test

\begin{tabular}{|llll|}
\hline Items & Path Coefficients-diff (MALE - FEMALE) & t-Value(IMALE vs FEMALEl) & p-Value (MALE vs FEMALE) \\
\hline ATE $->$ EI & -0.156 & 1.621 & 0.106 \\
\hline ATEE -> ATE & -0.081 & 0.420 & 0.675 \\
\hline ATEE -> PBC & -0.048 & 0.250 & 0.803 \\
\hline PBC -> EI & 0.116 & 1.093 & 0.276 \\
PSE -> ATE & -0.011 & 0.084 & 0.933 \\
\hline PSE - PBC & 0.240 & 2.032 & 0.043 \\
\hline SN_-> ATE & -0.023 & 0.182 & 0.856 \\
\hline SN_-> EI & 0.083 & 0.866 & 0.387 \\
SN_- PBC & 0.189 & 1.541 & 0.125 \\
\hline
\end{tabular}

Table 13

Welch-Satterthwait Test

\begin{tabular}{|llll|}
\hline Items & Path Coefficients-diff (MALE - FEMALE) & t-Value(IMALE vs FEMALEI) & p-Value (MALE vs FEMALE) \\
\hline ATE $>$ EI & -0.156 & 1.625 & 0.107 \\
\hline ATEE -> ATE & -0.081 & 0.417 & 0.677 \\
\hline ATEE -> PBC & -0.048 & 0.248 & 0.805 \\
\hline PBC -> El & 0.116 & 1.095 & 0.276 \\
\hline PSE -> ATE & -0.011 & 0.084 & 0.933 \\
\hline PSE -> PBC & 0.240 & 2.042 & 0.044 \\
\hline SN_-> ATE & -0.023 & 0.184 & 0.855 \\
\hline SN_-> EI & 0.083 & 0.870 & 0.386 \\
\hline SN_-> PBC & 0.189 & 1.546 & 0.125 \\
\hline
\end{tabular}


Table 14

Bootstrapping Results (for MGA)

\begin{tabular}{|c|c|c|c|c|c|c|c|c|c|c|}
\hline Items & $\begin{array}{l}\text { Path } \\
\text { Coefficients } \\
\text { Original } \\
\text { (FEMALE) }\end{array}$ & $\begin{array}{l}\text { Path } \\
\text { Coefficients } \\
\text { Original } \\
\text { (MÁLE) }\end{array}$ & $\begin{array}{l}\text { Path } \\
\text { Coefficients } \\
\text { Mean } \\
\text { (FEMALE) }\end{array}$ & $\begin{array}{l}\text { Path } \\
\text { Coefficients } \\
\text { Mean } \\
\text { (MALE) }\end{array}$ & $\begin{array}{l}\text { STDEV } \\
\text { (FEMALE) }\end{array}$ & $\begin{array}{l}\text { STDEV } \\
\text { (MALE) }\end{array}$ & $\begin{array}{l}\mathrm{t} \text {-Value } \\
\text { (FEMALE) }\end{array}$ & $\begin{array}{l}\text { t-Value } \\
\text { (MALE) }\end{array}$ & $\begin{array}{l}\text { p-Value } \\
\text { (FEMALE) }\end{array}$ & $\begin{array}{l}\text { p-Value } \\
\text { (MALE) }\end{array}$ \\
\hline $\begin{array}{l}\text { ATE - } \\
>\text { EI }\end{array}$ & 0.625 & 0.470 & 0.623 & 0.469 & 0.064 & 0.072 & 9.774 & 6.543 & 0.000 & 0.000 \\
\hline $\begin{array}{l}\text { ATEE } \\
-> \\
\text { ATE }\end{array}$ & -0.028 & -0.109 & -0.003 & -0.094 & 0.166 & 0.104 & 0.166 & 1.048 & 0.868 & 0.295 \\
\hline $\begin{array}{l}\text { ATEE } \\
-> \\
\text { PBC }\end{array}$ & 0.129 & 0.081 & 0.108 & 0.102 & 0.171 & 0.095 & 0.754 & 0.855 & 0.451 & 0.393 \\
\hline $\begin{array}{l}\text { PBC - } \\
>\text { El }\end{array}$ & 0.143 & 0.259 & 0.141 & 0.266 & 0.072 & 0.079 & 1.999 & 3.290 & 0.046 & 0.001 \\
\hline $\begin{array}{l}\text { PSE - } \\
> \\
\text { ATE }\end{array}$ & -0.050 & -0.060 & -0.055 & -0.049 & 0.085 & 0.095 & 0.580 & 0.634 & 0.562 & 0.526 \\
\hline $\begin{array}{l}\text { PSE - } \\
> \\
\text { PBC }\end{array}$ & -0.324 & -0.084 & -0.313 & -0.076 & 0.072 & 0.093 & 4.475 & 0.899 & 0.000 & 0.368 \\
\hline $\begin{array}{l}\mathrm{SN} \_ \\
\text {ATE }\end{array}$ & 0.494 & 0.472 & 0.485 & 0.468 & 0.068 & 0.105 & 7.319 & 4.512 & 0.000 & 0.000 \\
\hline $\mathrm{SN}_{\rightarrow \mathrm{EI}}$ & 0.203 & 0.286 & 0.206 & 0.278 & 0.060 & 0.075 & 3.371 & 3.818 & 0.001 & 0.000 \\
\hline $\begin{array}{l}\mathrm{SN}_{-} \\
\mathrm{PBC}\end{array}$ & 0.279 & 0.467 & 0.291 & 0.461 & 0.081 & 0.092 & 3.440 & 5.069 & 0.001 & 0.000 \\
\hline
\end{tabular}

Table 15

Confidence intervals (Bias Corrected)

\begin{tabular}{|lllll|}
\hline Items & $\mathbf{2 . 5 \%}$ (FEMALE) & $\mathbf{9 7 . 5 \%}$ (FEMALE) & $\mathbf{2 . 5 \%}$ (MALE) & $\mathbf{9 7 . 5 \%}$ (MALE) \\
\hline ATE -> EI & 0.490 & 0.740 & 0.319 & 0.600 \\
\hline ATEE -> ATE & -0.390 & 0.224 & -0.326 & 0.077 \\
\hline ATEE -> PBC & -0.305 & 0.331 & -0.217 & 0.237 \\
\hline PBC -> El & -0.011 & 0.272 & 0.128 & 0.433 \\
\hline PSE -> ATE & -0.214 & 0.123 & -0.243 & 0.126 \\
\hline PSE -> PBC & -0.459 & -0.185 & -0.265 & 0.092 \\
\hline SN_-> ATE & 0.353 & 0.613 & 0.239 & 0.655 \\
\hline SN_-> EI & 0.085 & 0.319 & 0.139 & 0.428 \\
\hline SN_-> PBC & 0.091 & 0.414 & 0.273 & 0.631 \\
\hline
\end{tabular}

\subsection{F Square}

The $\mathrm{f}$-square equation expresses how large a proportion of unexplained variance is accounted for by $R^{2}$ change (Hair et al., 2014). The effect size is assessed with a tool known as F Square indicated in Table 16 and Fig. 8. Following Cohen (1988) an F Square value of above 0.35 is considered large effect size; values ranging from 0.15 to 0.35 are medium effect size; values between 0.02 and 0.15 are considered small effect and values less than 0.02 are considered NO effect size. From Fig. 4 it can be observed that the ATE-El relationship is the highest i.e. 0.724 . This is followed by $\mathrm{SN}-\mathrm{ATE}$ and $\mathrm{SN}-\mathrm{PBC}$ respectively. 


\subsection{Mediation Analysis}

Table 16

F Square

\begin{tabular}{|c|c|c|c|c|c|c|}
\hline & ATE & ATEE & El & PBC & PSE & SN \\
\hline ATE & & & 0.724 & & & \\
\hline ATEE & 0.004 & & & 0.001 & & \\
\hline \multicolumn{7}{|l|}{ EI } \\
\hline PBC & & & 0.101 & & & \\
\hline PSE & 0.000 & & & 0.065 & & \\
\hline SN & 0.348 & & 0.101 & 0.253 & & \\
\hline
\end{tabular}

According to Aguinis et al. (2017), mediation refers to the presence of an intermediate variable or mechanism that transmits the effect of an antecedent variable to an outcome. The framework (Fig. 1) for this study called for multiple mediation analysis. As shown in Table 17, there are three Total Indirect Effects. However, the Specific Indirect Effects were six as depicted in Table 18. Tables 17 and 18 reveal the running of the Consistent Algorithm. To identify which of the variables were significant we run the Consistent Bootstrapping. The results are found in Tables 19 and 20. As shown in Table 20 it can be seen that SN->ATE->El and SN->PBC->El are significant.

Table 17

PLSc Algorithm TOTAL INDIRECT EFFECTS

\begin{tabular}{|c|c|c|c|c|c|c|}
\hline & ATE & ATEE & EI & PBC & PSE & SN \\
\hline \multicolumn{7}{|l|}{ ATE } \\
\hline ATEE & & & -0.028 & & & \\
\hline \multicolumn{7}{|l|}{$\mathrm{EI}$} \\
\hline \multicolumn{7}{|l|}{ PBC } \\
\hline PSE & & & -0.050 & & & \\
\hline SN & & & 0.404 & & & \\
\hline
\end{tabular}

Table 18

PLSc Algorithm SPECIFIC INDIRECT EFFECTS

\begin{tabular}{|ll|}
\hline & SPECIFIC INDIRECT EFFECTS \\
\hline ATEE->ATE->EI & -0.032 \\
\hline PSE->ATE->EI & -0.003 \\
SN->ATE->EI & 0.308 \\
\hline ATEE->PBC->EI & 0.005 \\
PSE->PBC->EI & -0.046 \\
\hline SN->PBC->EI & 0.095 \\
\hline
\end{tabular}


Table 19

Bootstrapping (c) TOTAL INDIRECT EFFECTS

\begin{tabular}{|c|c|c|c|c|c|}
\hline & Original & Sample & Standard & T Statistic & P Values \\
\hline \multicolumn{6}{|l|}{ ATE->El } \\
\hline \multicolumn{6}{|c|}{ ATEE->ATE } \\
\hline ATEE->EI & -0.037 & -0.026 & 0.080 & 0.466 & 0.642 \\
\hline \multicolumn{6}{|c|}{ ATEE->PBC } \\
\hline \multicolumn{6}{|l|}{ PBC->EI } \\
\hline \multicolumn{6}{|l|}{ PSE->ATE } \\
\hline PSE->EI & -0.063 & -0.062 & 0.060 & 1.047 & 0.295 \\
\hline \multicolumn{6}{|l|}{ PSE->PBC } \\
\hline \multicolumn{6}{|l|}{ SN->ATE } \\
\hline $\mathrm{SN}->\mathrm{EI}$ & 0.400 & 0.397 & 0.067 & 6.008 & 0.000 \\
\hline $\mathrm{SN}->\mathrm{PBC}$ & & & & & \\
\hline
\end{tabular}

Table 20

Bootstrapping (c) SPECIFIC INDIRECT EFFECTS

\begin{tabular}{|llllll|}
\hline & Original & Sample & Standard & T Statistic & P Values \\
\hline ATEE->ATE->EI & -0.043 & -0.033 & 0.066 & 0.650 & 0.516 \\
\hline PSE->ATE->EI & -0.013 & -0.013 & 0.047 & 0.286 & 0.775 \\
\hline SN->ATE->EI & 0.308 & 0.303 & 0.056 & 5.535 & 0.000 \\
\hline ATEE->PBC->EI & 0.006 & 0.007 & 0.030 & 0.187 & 0.852 \\
\hline PSE->PBC->EI & -0.050 & -0.049 & 0.027 & 1.825 & 0.068 \\
\hline SN->PBC->EI & 0.093 & 0.094 & 0.040 & 2.310 & 0.021 \\
\hline
\end{tabular}

\subsection{Discussion}

The main claim of the TPB is that intention is influenced by three variables, i.e. ATE, SNs, and PBC. This exposition of the Ajzen model lays the foundation for the hypotheses which tested the validity of the model in the present paper. Specifically, we investigated the moderating effect of gender on ATEE and Role Models by applying the theory of planned behavior (1991). Though empirical studies in entrepreneurship have produced contradictory results, we proceeded to apply the TPB to examine students' entrepreneurial intention because it is probably one of the most tried and tested theories in entrepreneurial research. We explored the extent to which Parental Self-employment and entrepreneurship education impact entrepreneurial intentions. We formulated two categories of hypotheses; primary and secondary and conducted a tripartite analysis for Complete, Male and Female models.

This study underscored ATE as one of the important determinants of our framework, exhibiting a strong and highly significant relationship between ATE and entrepreneurial intention. This confirms the findings of Krueger et al. (2000) and Mahfud, Bruri, Sudira, and Mulyani (2020) who reported that ATE has a significant direct relationship with entrepreneurial intention.

Regarding the Complete and Male Models, all the primary hypotheses were accepted. However, with the Female Model four out of the primary hypotheses were accepted. These results are in line with previous studies which found that SNs have a significant positive correlation with ATE and PBC (Entrialgo \& Iglesias, 2016; Liñán \& Santos, 2007; Liñán et al., 2011 ).

The relationship between ATEE and El, and PSE and El were both insignificant. Bae et al. (2014), in their paper, reported a statistically significant but small positive relationship between entrepreneurship education and entrepreneurial intentions.

With regards to the relationship between PSE/Role Models, the results points out that having a parent who is an entrepreneur positively influence a student's PBC (for the Complete and Female models), most probably increasing one's knowledge, mastery, or general set of ability 
with regard to engaging in tasks required for becoming an entrepreneur (BarNir, Watson \& Hutchins. 2011). Interestingly, there was an insignificant relationship between PSE/Role Models and PBC for the male respondents.

According to this study the relationship between PSE and PBC is stronger for Males than Females, hence H13 is accepted. According to Wilson, Marlino and Kickul (2004) women tend to shy away from entrepreneurial activity more frequently than men due to a lower perception of perceived self-efficacy in carry out entrepreneurial tasks. Verheul, Uhlaner and Thurik (2003) buttress this by emphasizing that females less frequently perceive themselves as entrepreneurs.

However, this study fails to certain support certain aspects of previous studies on how exposure to entrepreneurial education and role models impact on Males and Females. Thus hypotheses $\mathrm{H} 12, \mathrm{H} 14$ and $\mathrm{H} 15$ were not supported hence there was no significant relationship between Males and Females. The influence of ATEE on PBC was not significant. These findings are consistent with those of Entrialgo and Iglesias (2017). We established non-significant impacts on gender and parental self-employment. These results are in line with a paper by Bae et al. (2014).

This study has confirmed the applicability of the TPB model to entrepreneurial intention and the moderating role of gender. However, we did not find a significant relationship between Males and Females concerning their entrepreneurial intentions for $\mathrm{H} 12, \mathrm{H} 14$ and $\mathrm{H} 15$. Therefore gender had no significance on the path coefficients. That means the gender of a student doesn't affect the link between attitude towards entrepreneurship education and El. The finding further revealed that gender has no influence on the relationship between attitude and intention, which was supported by Nowinski et al. (2019) and (Jena, 2020). These results are inconsistent with those of Santos et al. (2016) who found that Males display higher entrepreneurial intentions than Females.

\subsection{Implications And Direction For Future Research}

This study has some interesting implications. First, ATE came out as the most important variable of the model and this implies that entrepreneurial attitudes may be influenced by the relevant stakeholders in academic circles. Though we did not establish a positive correlation between PSE and ATE, influential role models can support nascent entrepreneurs. We recommend the institutionalization of traineeship, elective courses, conference and workshops on entrepreneurship to boost the entrepreneurial spirit of students. Also, policy-makers can motivate students by providing some fiscal incentives to allow individual and business angel investments in the seed stage of their entrepreneurial activities (European Commission, 2020).

Our paper extends the studies of Trivedi (2016) by introducing Role Model or Parental Self-employment as an additional antecedent and gender as a moderating variable. This study also proximately mirrors the study by Entrialgo and Iglesias (2017), though our study used a Likert scale to measure entrepreneurial education instead of a dichotomous variable.

Though we found no significant relationship for ATEE on El, we suggest that educators and the relevant stakeholders focus on how to stimulate entrepreneurial intentions through education.

Notwithstanding the importance of entrepreneurship education in the development of entrepreneurial intentions, this paper revealed that ATEE has no significant impact on ATE and PBC. This will probably call for early engagement of the students to expose them to entrepreneurial education (Entrialgo \& Iglesias, 2017).

The findings contribute to research on parental self-employment (PSE). The results indicate that role model or parental self-employment impact on PBC for the Complete and the Female models. However, there was an insignificant relationship between parental self-employed and PBC for the Male model.

\subsection{Limitations}

In considering the generalizability of this paper, it is important to highlight some limitations. First, the respondents were sampled from a single university in Spain. It will be exciting to replicate the study with a multi-country sample to identify the dynamics of ATEE and Role Models in those countries.

Also, the majority of the students were from the Faculty of Law and Business Administration, leading to skewness of the sample characteristics.

Furthermore, the insufficient number of samples in the subgroups (Male and Female) has the potential of reducing the power of analysis, leading to sampling error (Hunter \& Schmidt, 2004).

\subsection{Conclusions}


The paper has contributed to the existing literature on the multi-group analysis of gender on entrepreneurial intentions among university students. Although the differences between Males and Females were not significant for three of the relationships, the applicability of the TPB to measure entrepreneurial intentions has been supported.

\section{Declarations}

\section{Funding}

The authors have no funding to report.

\section{Competing Interests}

The authors have declared that no competing interests exist.

\section{Acknowledgments}

The authors have no support to report.

\section{References}

1. Aguinis, H., Edwards, J. R., \& Bradley, K. J. (2017). Improving Our Understanding of Moderation and Mediation in Strategic Management Research. Organizational Research Methods, 20(4), 665-685. https://doi.org/10.1177/1094428115627498.

2. Ajzen, I. (2002). Behavioral Interventions Based on the Theory of Planned Behavior. Research Policy, 2011, 1-6. https://doi.org/10.1016/j.respol.2007.07.006.

3. Armitage, C. J., \& Conner, M. (2001). <Armitage and Connor 2001.Pdf>. British Journal of Social Psychology, 40, 471. Retrieved from https://pdfs.semanticscholar.org/ab83/87ae29317c651a129efc7a2297bc5f348a95.pdf

4. Audretsch, D., Horst, R., Van Der, \& Thurik, R. (2009). F i r s t S e c t i o n o f t he A n n u a I Re p o r t o n E U S m a I I a n d M e d i u m- si z e dEnterprises.

5. Autio, E., Keeley, R. H., Klofsten, M., Parker, G. G. C., \& Hay, M. (2001). Entrepreneurial Intentions among Business Students in. Enterprise and Innovation Management Studies, 2(2), 145-160. https://doi.org/10.1080/1463244011009463.

6. Bae, T. J., Qian, S., Miao, C., \& Fiet, J. O. (2014). The Relationship Between Entrepreneurship Education and Entrepreneurial Intentions: A Meta-Analytic Review. Entrepreneurship: Theory and Practice, 38(2), 217-254. https://doi.org/10.1111/etap.12095.

7. Becker, J., Ringle, C. M., \& Hreats, A. V. V. A. T. (2013). Discovering Unobserved Heterogeneity in Structural Equation Models to Avert Validity Threats, 37(September), 665-694.

8. Bird, B. (1988). Implementing Entrepreneurial Ideas: The Case for Intention. Academy of Management Review, 13(3), $442-453$. https://doi.org/10.5465/amr.1988.4306970.

9. Block, J. H., Hoogerheide, L., \& Thurik, R. (2013). Education and entrepreneurial choice: An instrumental variables analysis. International Small Business Journal, 31(1), 23-33. https://doi.org/10.1177/0266242611400470.

10. Díaz-garcía, M. C., \& Jiménez-moreno, J. (2010). Entrepreneurial intention: the role of gender, (January 2009), $261-283$. https://doi.org/10.1007/s11365-008-0103-2.

11. Entrialgo, M., \& Iglesias, V. (2017). Are the Intentions to Entrepreneurship of Men and Women Shaped Differently? the Impact of Entrepreneurial Role-Model Exposure and Entrepreneurship Education. Entrepreneurship Research Journal, 8(1), 1-14. https://doi.org/10.1515/erj-2017-0013.

12. Entrialgo, M., \& Iglesias, V. (2016). The moderating role of entrepreneurship education on the antecedents of entrepreneurial intention. International Entrepreneurship and Management Journal, 12(4), 1209-1232. https://doi.org/10.1007/s11365-016-0389-4.

13. Fayolle, A., \& Gailly, B. (2015). on Entrepreneurial Attitudes and Intention. Hysteresis and Persistence, 53(1), 75-93. https://doi.org/10.1111/jsbm.12065.

14. Fayolle, A., Gailly, B., \& Lassas-Clerc, N. (2006). Assessing the impact of entrepreneurship education programmes: A new methodology. Journal of European Industrial Training (Vol. 30). https://doi.org/10.1108/03090590610715022.

15. Fornell, C., \& Larcker, D. F. (1981). Evaluating Structural Equation Models with Unobservable Variables and Measurement Error, XVi(February), 39-50.

16. Garson, G. D. (2016). Partial Least Squares: Regression \& Structural Equation Models. G. David Garson and Statistical Associates Publishing. 
17. Henderson, R., \& Robertson, M. (1999). Who wants to be an entrepreneur? Young adult attitudes to entrepreneurship as a career. Education + Training, 41(5), 236-245. https://doi.org/10.1108/00400919910279973.

18. Hindle, K., Klyver, K., \& Jennings, D. F. (2009). Understanding the Entrepreneurial Mind. Understanding the Entrepreneurial Mind, (May), 3450. https://doi.org/10.1007/978-1-4419-0443-0.

19. Hughes, K. D., Jennings, J. E., Brush, C., Carter, S., \& Welter, F. (2012). Extending Women's Entrepreneurship Research in New Directions. Entrepreneurship: Theory and Practice, 36(3), 429-442. https://doi.org/10.1111/j.1540-6520.2012.00504.x.

20. Hult, G. T. M., Jr, D. J. K., Griffith, D. A., Finnegan, C. A., Gonzalez-padron, T., Harmancioglu, N., ... Talay, M. B. (2008). Data equivalence in cross-cultural international business research: assessment and guidelines, 1027-1044. https://doi.org/10.1057/palgrave.jibs.8400396.

21. lakovleva, T., \& Kolvereid, L. (2009). An integrated model of entrepreneurial intentions. International Journal of Business and Globalisation, 3(1), 66. https://doi.org/10.1504/IJBG.2009.021632.

22. Jena, R. K. (2020). Measuring the impact of business management Student's attitude towards entrepreneurship education on entrepreneurial intention: A case study. Computers in Human Behavior, 107(January). https://doi.org/10.1016/j.chb.2020.106275.

23. Kolvereid_1996 (1).pdf. (n.d.).

24. Kolvereid, L., \& Isaksen, E. (2006). New business start-up and subsequent entry into self-employment. Journal of Business Venturing, 21(6), 866-885. https://doi.org/10.1016/j.jbusvent.2005.06.008.

25. Kolvereid, L., \& Moen, $\varnothing$ (1997). Entrepreneurship among business graduates: does a major in entrepreneurship make a difference? Journal of European Industrial Training, 21(4), 154-160. https://doi.org/10.1108/03090599710171404.

26. Krueger, N. F. (1993). Growing up entreprenereurial? Some developmental consequences of early exposure to entrepreneurship. Academy of Management, 80-84.

27. Krueger, N. F., Reilly, M. D., \& Carsrud, A. L. (2000). Competing models of entrepreneurial intentions. Journal of Business Venturing, 15(5), 411-432. https://doi.org/10.1016/S0883-9026(98)00033-0.

28. Lerner, J. (2004). The university and the start-up: Lessons from the past two decades. Journal of Technology Transfer, 30(1-2), 49-56. https://doi.org/10.1007/s10961-004-4357-8.

29. Liñán, F. (2008). Skill and value perceptions: How do they affect entrepreneurial intentions? International Entrepreneurship and Management Journal, 4(3), 257-272. https://doi.org/10.1007/s11365-008-0093-0.

30. Liñán, F., \& Chen, Y. (2009). Development and Cross-Cultural Application of a Specific Instrument to Measure Entrepreneurial Intentions Francisco. Entrepreneurship Theory \& Practice, 593-617.

31. Liñán, F., Rodríguez-Cohard, J. C., \& Rueda-Cantuche, J. M. (2011). Factors affecting entrepreneurial intention levels: A role for education. International Entrepreneurship and Management Journal, 7(2), 195-218. https://doi.org/10.1007/s11365-010-0154-z.

32. Liñán, F., \& Santos, F. J. (2007). Does social capital affect entrepreneurial intentions? International Advances in Economic Research, 13(4), 443-453. https://doi.org/10.1007/s11294-007-9109-8.

33. Liñán, F., Urbano, D., \& Guerrero, M. (2011). Regional variations in entrepreneurial cognitions: Start-up intentions of university students in Spain. Entrepreneurship and Regional Development, 23(3-4), 187-215. https://doi.org/10.1080/08985620903233929.

34. Mahfud, T., Bruri, M., Sudira, P., \& Mulyani, Y. (2020). The influence of social capital and entrepreneurial attitude orientation on entrepreneurial intentions: the mediating role of psychological capital, 26, 33-39.

35. Mian, S. A. (1997). Assessing and managing the university technology business incubator: An integrative framework. Journal of Business Venturing, 12(4), 251-285. https://doi.org/10.1016/S0883-9026(96)00063-8.

36. Moriano, J. A., Gorgievski, M., Laguna, M., Stephan, U., \& Zarafshani, K. (2012). A Cross-Cultural Approach to Understanding Entrepreneurial Intention. Journal of Career Development, 39(2), 162-185. https://doi.org/10.1177/0894845310384481.

37. Nguyen, A. T., Do, T. H. H., Vu, T. B. T., Dang, K. A., \& Nguyen, H. L. (2019). Factors affecting entrepreneurial intentions among youths in Vietnam. Children and Youth Services Review, 99(November 2018), 186-193. https://doi.org/10.1016/j.childyouth.2019.01.039.

38. Nowinski, W., Mohamed, Y., Haddoud, Lancaric, D., Dana, E., \& Czegledi, C. (2019). The impact of entrepreneurship education, entrepreneurial self-efficacy and gender on entrepreneurial intentions of university students in the Visegrad countries. Studies in Higher Education, 44(2), 361-379.

39. Oosterbeek, H., van Praag, M., \& ljsselstein, A. (2010). The impact of entrepreneurship education on entrepreneurship skills and motivation. European Economic Review, 54(3), 442-454. https://doi.org/10.1016/j.euroecorev.2009.08.002.

40. Peterman, N. E., \& Kennedy, J. (2003). E T \& P Enterprise Education: Influencing Students '. Entrepreneurship Theory and Practice, $129-144$.

41. Sánchez-Franco, M. J., \& Roldán, J. L. (2005). Web acceptance and usage model: A comparison between goal-directed and experiential web users. Internet Research, 15(1), 21-48. https://doi.org/10.1108/10662240510577059. 
42. Santos, F. J., Roomi, M. A., \& Liñán, F. (2016). About Gender Differences and the Social Environment in the Development of Entrepreneurial Intentions. Journal of Small Business Management, 54(1), 49-66. https://doi.org/10.1111/jsbm.12129.

43. Scherer, R. F., Adams, J. S., Carley, S. S., \& Wiebe, F. A. (1989). Role Model Performance Effects on Development of Entrepreneurial Career Preference. Entrepreneurship Theory and Practice, 13(3), 53-72. https://doi.org/10.1177/104225878901300306.

44. Souitaris, V., Zerbinati, S., \& Al-Laham, A. (2007). Do entrepreneurship programmes raise entrepreneurial intention of science and engineering students? The effect of learning, inspiration and resources. Journal of Business Venturing, 22(4), 566-591. https://doi.org/10.1016/j.jbusvent.2006.05.002.

45. Stephens, K. (n.d.), Parents Are Powerful Role Models for Children.

46. Trivedi, R. (2016). Does university play significant role in shaping entrepreneurial intention? A cross-country comparative analysis. Journal of Small Business and Enterprise Development, 23(3), 790-811. https://doi.org/10.1108/JSBED-10-2015-0149.

47. Turker, D., \& Selcuk, S. S. (2009). Which factors affect entrepreneurial intention of university students? Journal of European Industrial Training, 33(2), 142-159. https://doi.org/10.1108/03090590910939049.

48. Urbano, D., \& Guerrero, M. (2013). Entrepreneurial Universities: Socioeconomic Impacts of Academic Entrepreneurship in a European Region. Gender and Society, 27(1), 40-55. https://doi.org/10.1177/0891242412471973.

49. Valliere, D. (2016). Measuring Regional Variations of Entrepreneurial Intent in India. Journal of Entrepreneurship, 25(2), 111-128. https://doi.org/10.1177/0971355716650362.

50. Verheul, I., Thurik, R., Grilo, I., \& Van der Zwan, P. (2012). Explaining preferences and actual involvement in self-employment: Gender and the entrepreneurial personality. Journal of Economic Psychology, 33(2), 325-341. https://doi.org/10.1016/j.joep.2011.02.009.

51. von Graevenitz, G., Harhoff, D., \& Weber, R. (2010). The effects of entrepreneurship education. Journal of Economic Behavior and Organization, 76(1), 90-112. https://doi.org/10.1016/j.jebo.2010.02.015.

52. Walter, A., Auer, M., \& Ritter, T. (2006). The impact of network capabilities and entrepreneurial orientation on university spin-off performance. Journal of Business Venturing, 21(4), 541-567. https://doi.org/10.1016/j.jbusvent.2005.02.005.

53. Walter, S. G., \& Dohse, D. (2012). Why mode and regional context matter for entrepreneurship education. Entrepreneurship and Regional Development, 24(9-10), 807-835. https://doi.org/10.1080/08985626.2012.721009.

54. Zellweger, T., Sieger, P., \& Halter, F. (2011). Should I stay or should I go? Career choice intentions of students with family business background. Journal of Business Venturing, 26(5), 521-536. https://doi.org/10.1016/j.jbusvent.2010.04.001.

55. Zhang, Y., Duysters, G., \& Cloodt, M. (2014). The role of entrepreneurship education as a predictor of university students' entrepreneurial intention. International Entrepreneurship and Management Journal, 10(3), 623-641. https://doi.org/10.1007/s11365-012-0246-z.

56. Zhao, H., Hills, G. E., \& Seibert, S. E. (2005). The mediating role of self-efficacy in the development of entrepreneurial intentions. Journal of Applied Psychology, 90(6), 1265-1272. https://doi.org/10.1037/0021-9010.90.6.1265.

\section{Figures}




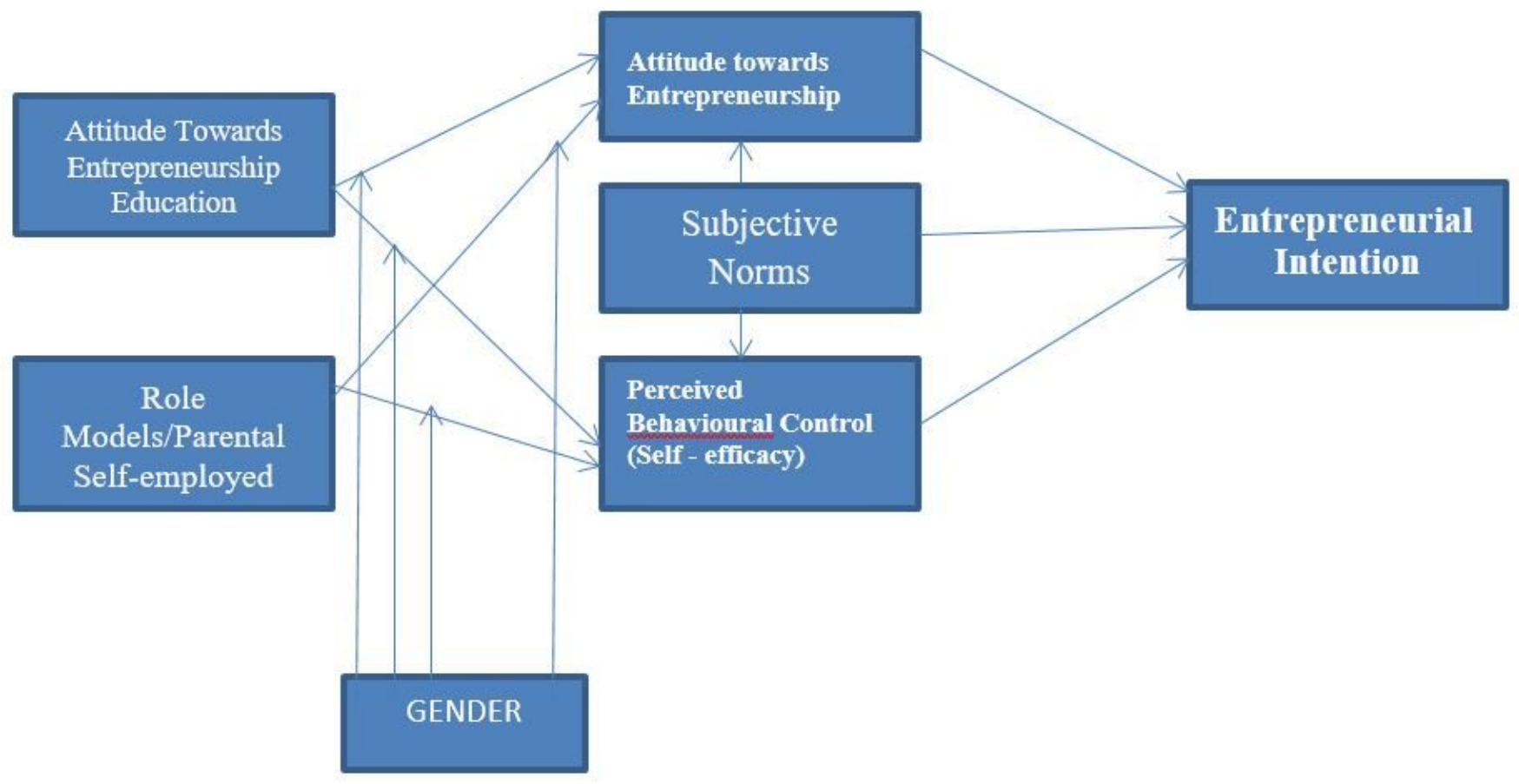

Figure 1

ENTREPRENEURIAL INTENTION-UNIVERSITY SUPPORT MODEL

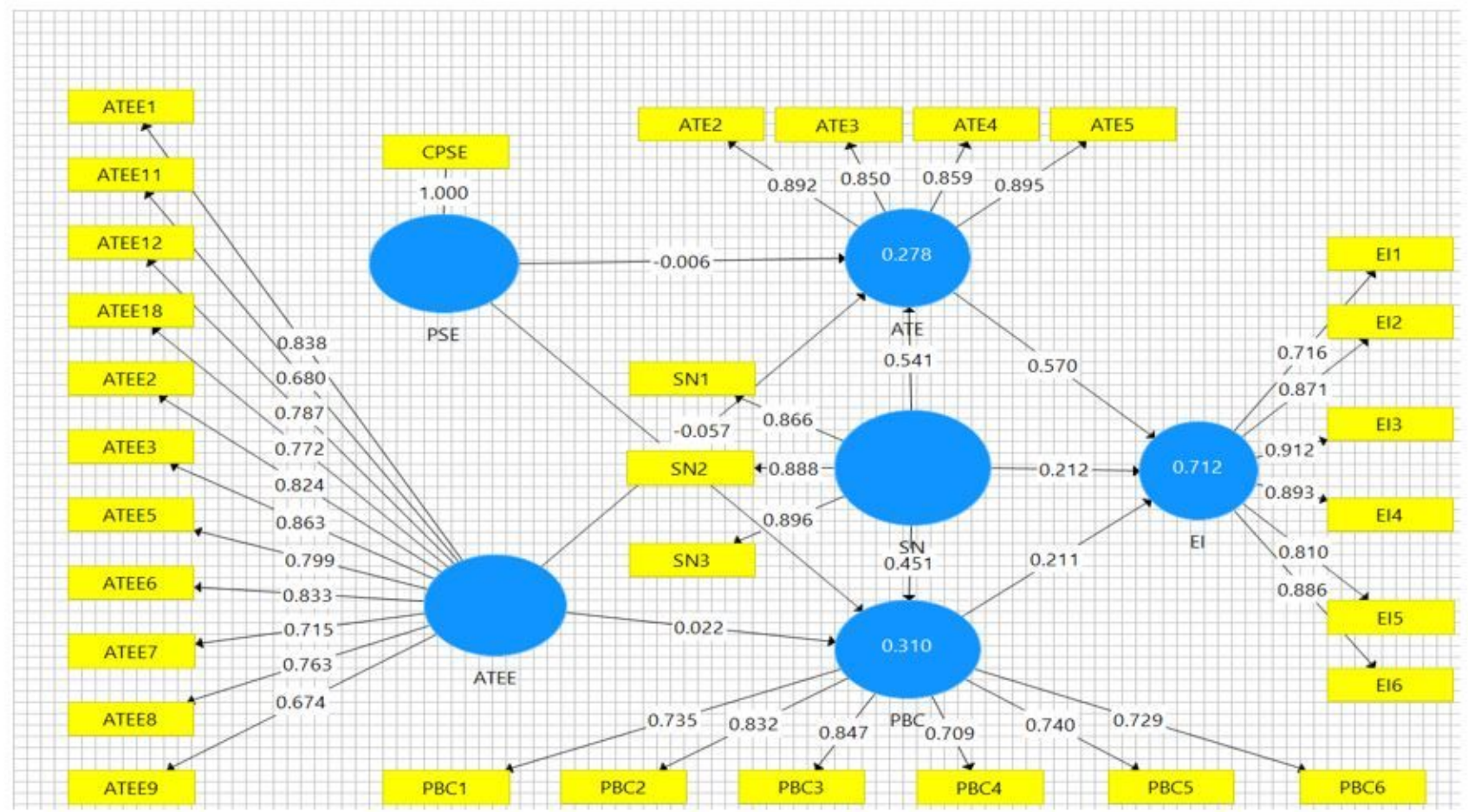

Figure 2

COMPLETE 


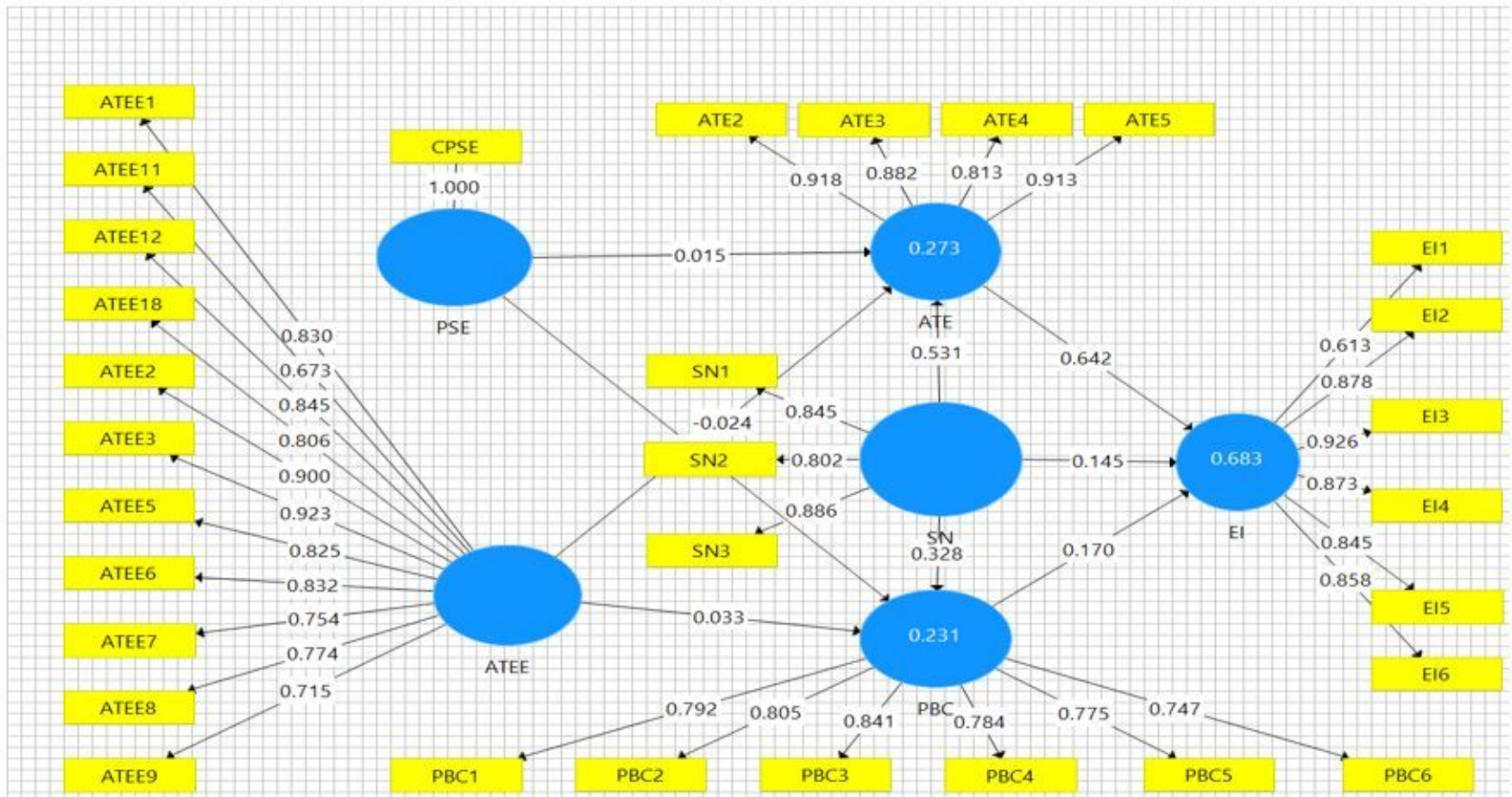

Figure 3

\section{FEMALE}

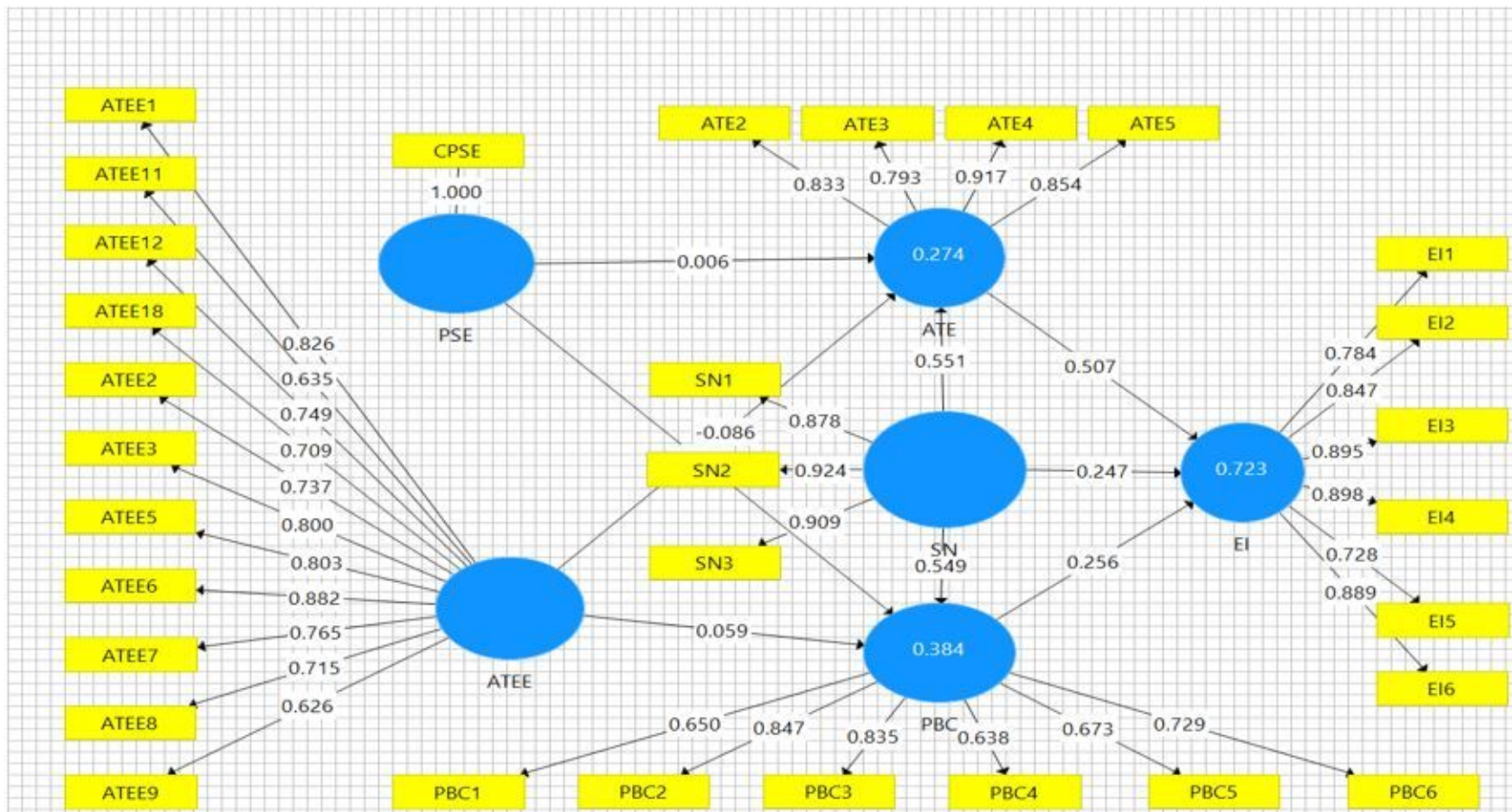

\section{Figure 4}

MALE 


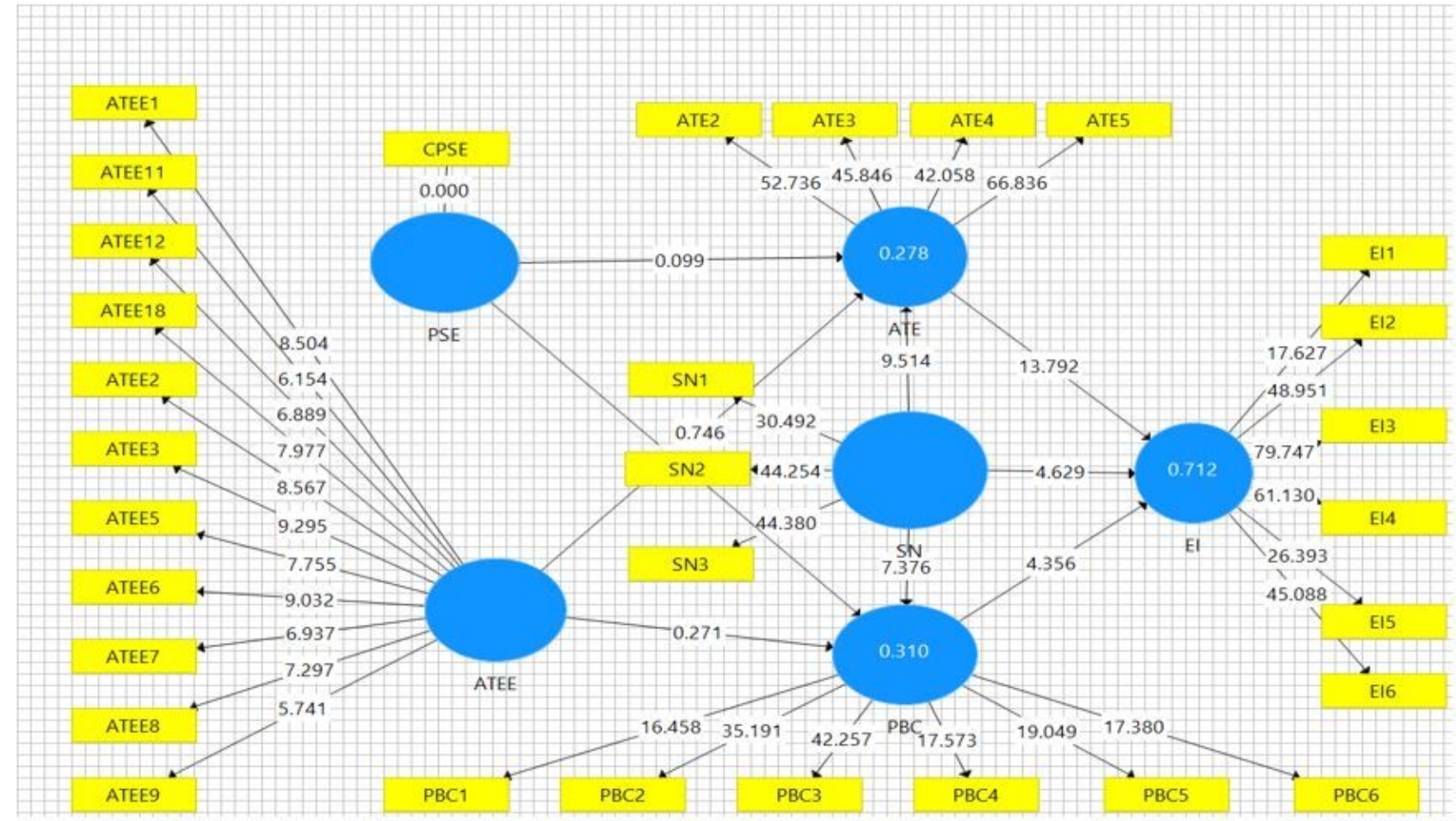

Figure 5

Bootstrapping (Complete)

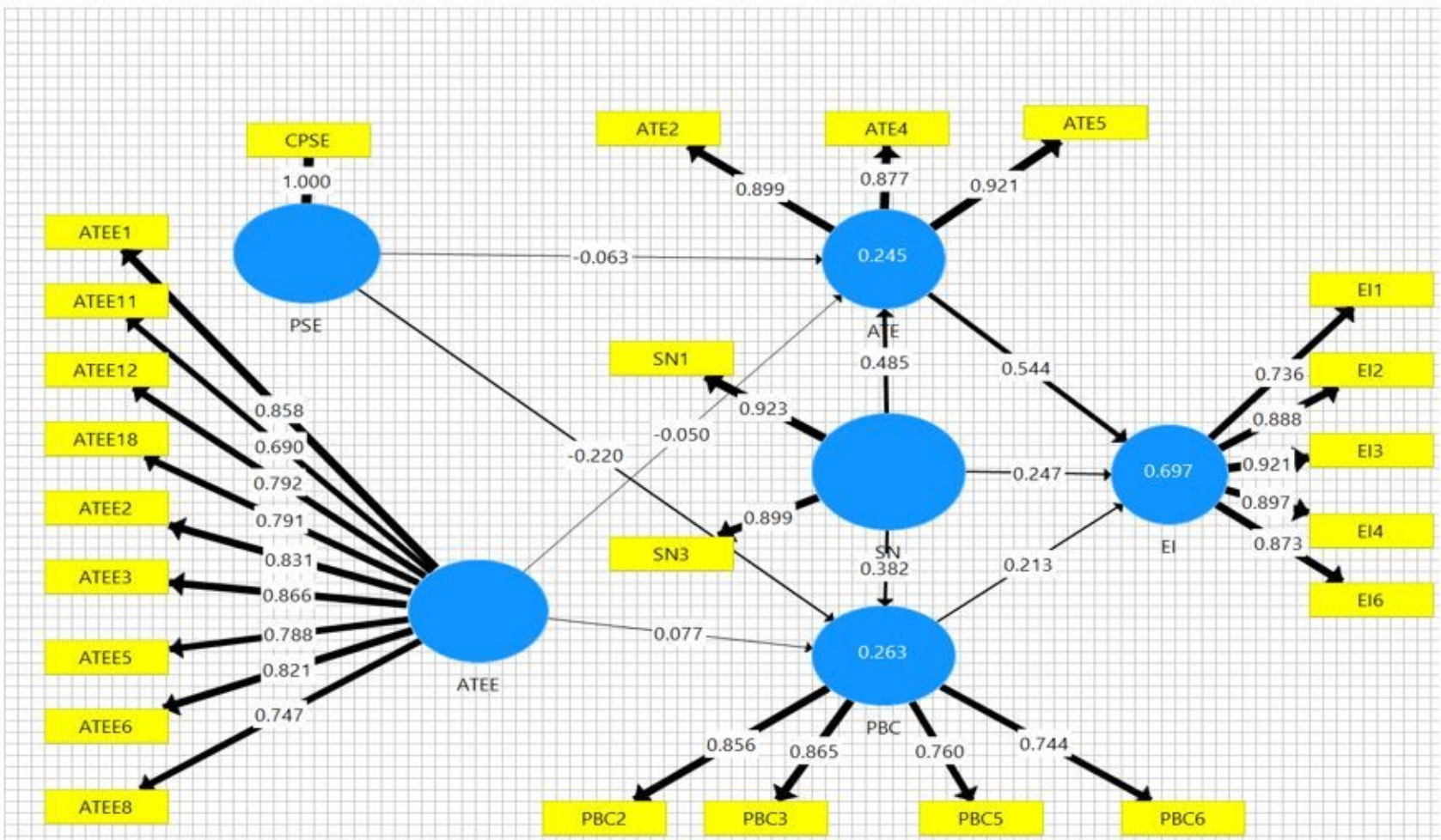

Figure 6

MGA ALGORITHM 


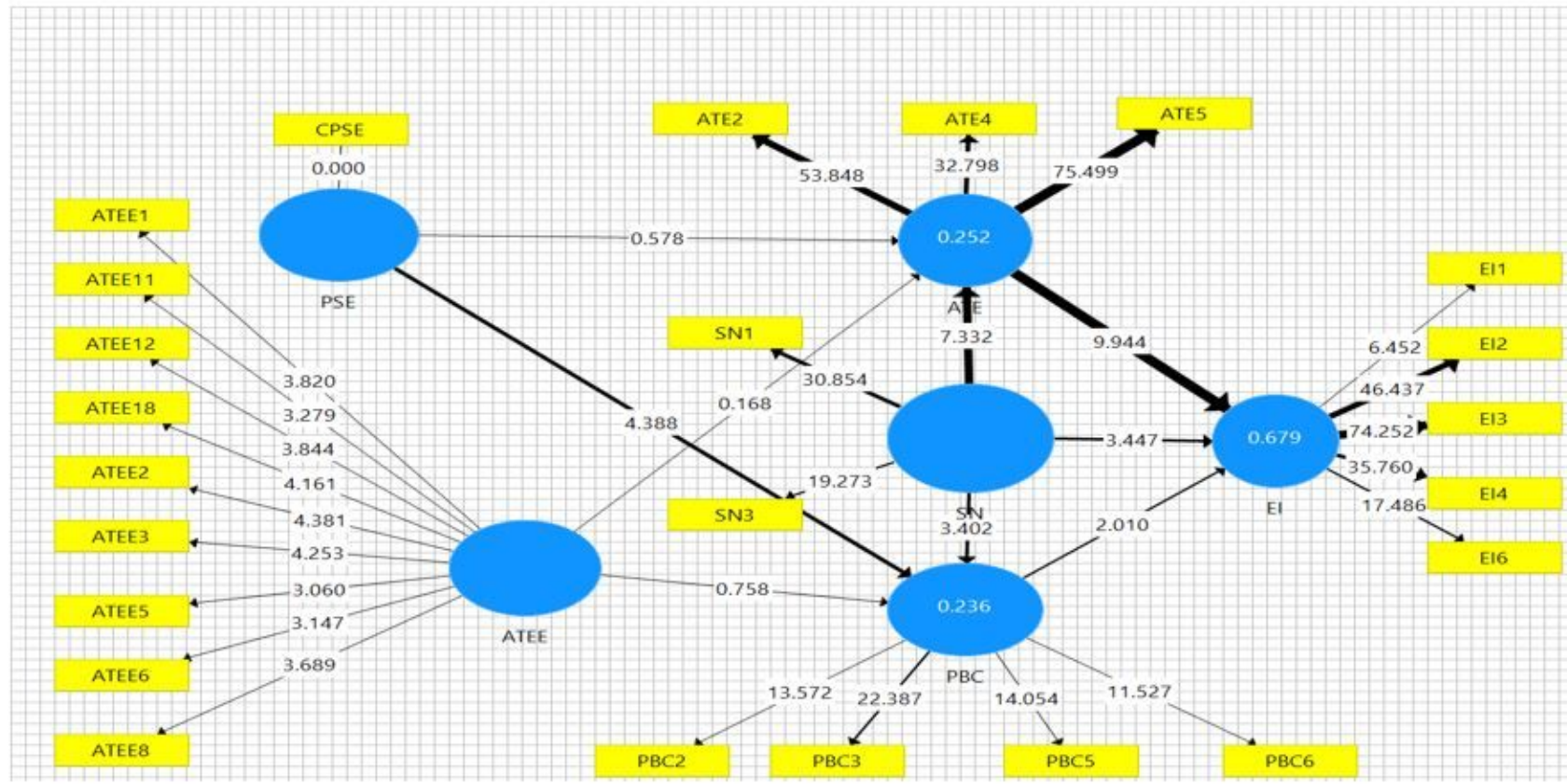

Figure 7

MGA FEMALE

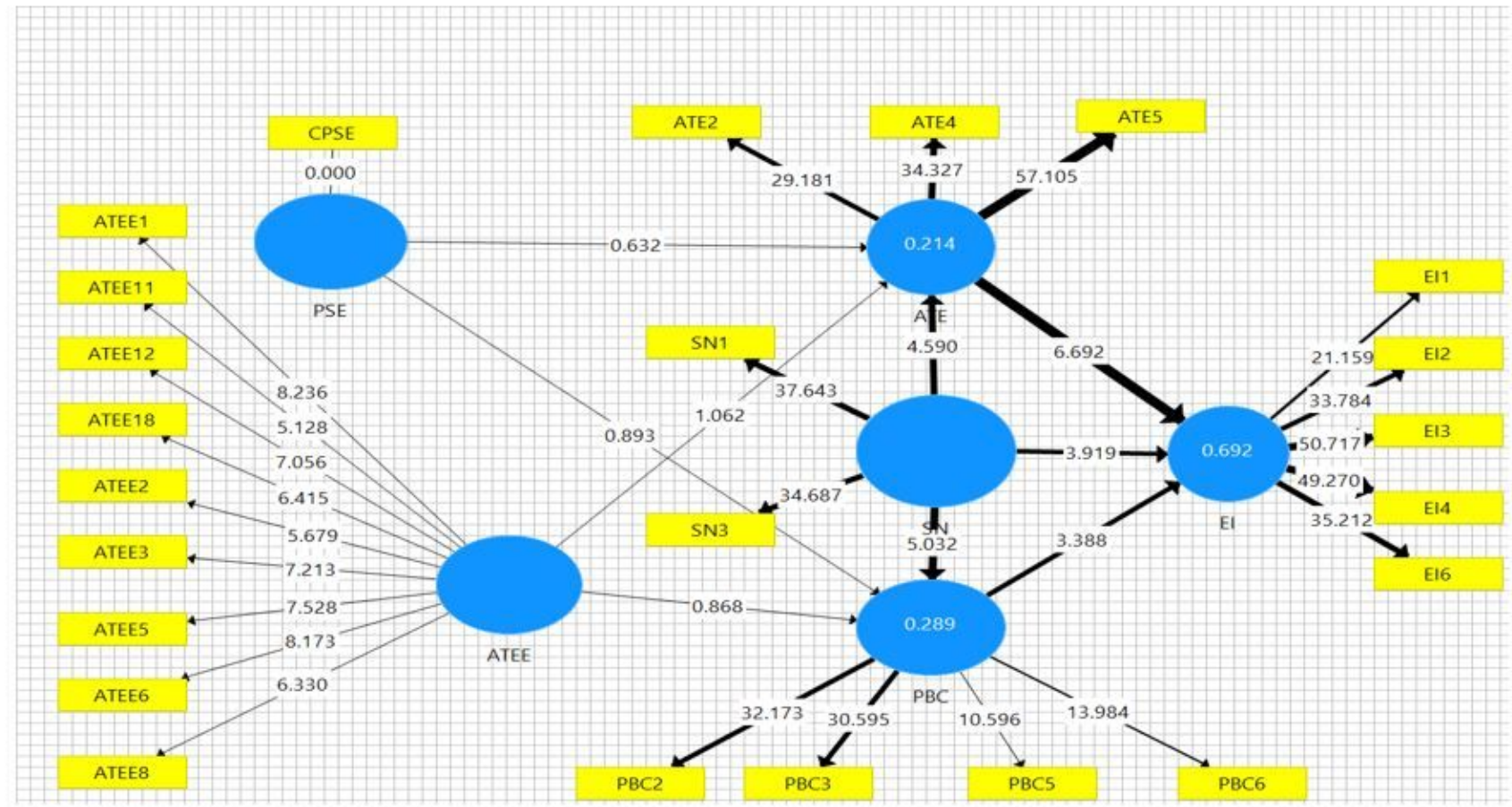

Figure 8

MGA MALE 


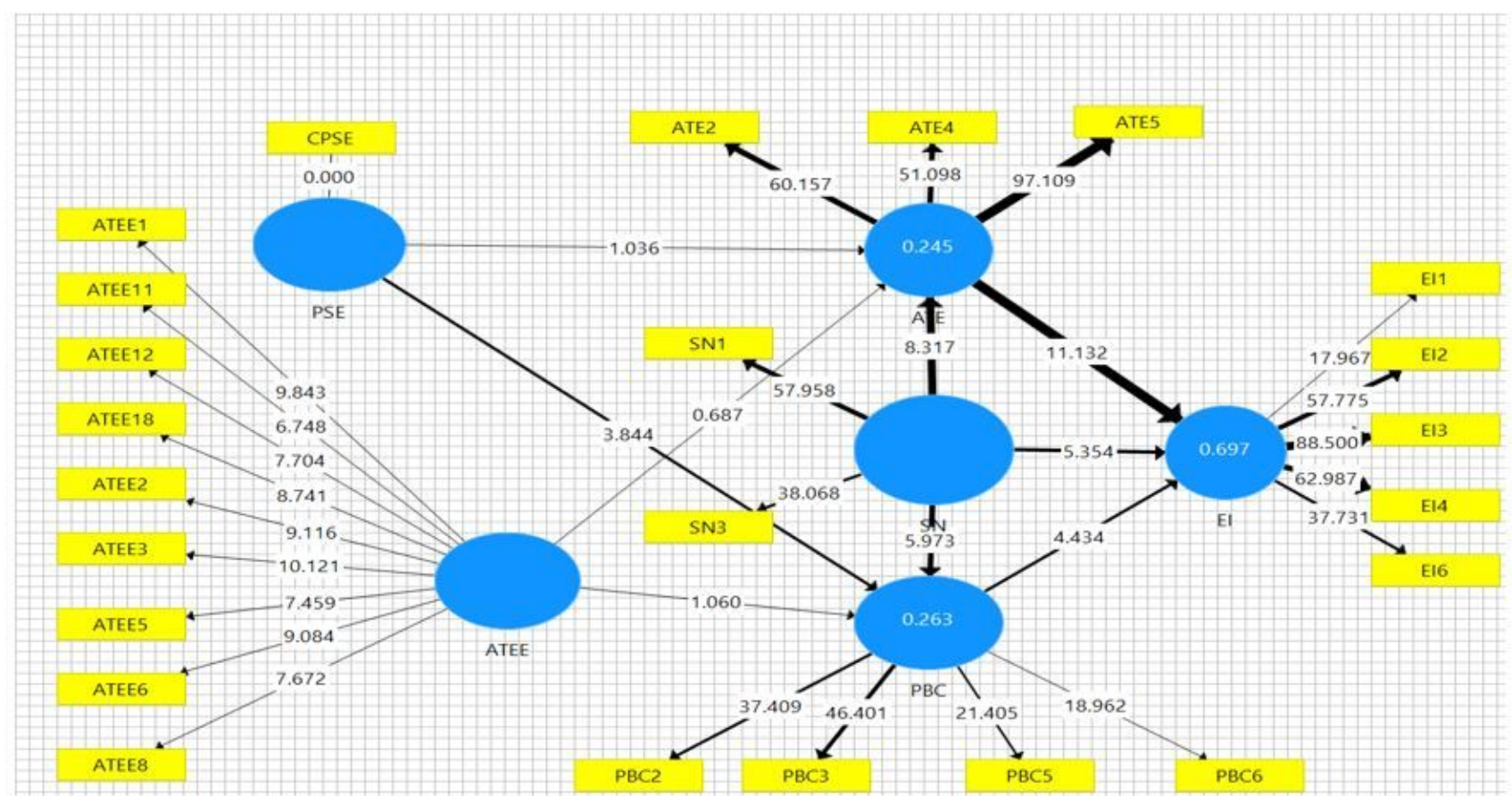

Figure 9

Complete

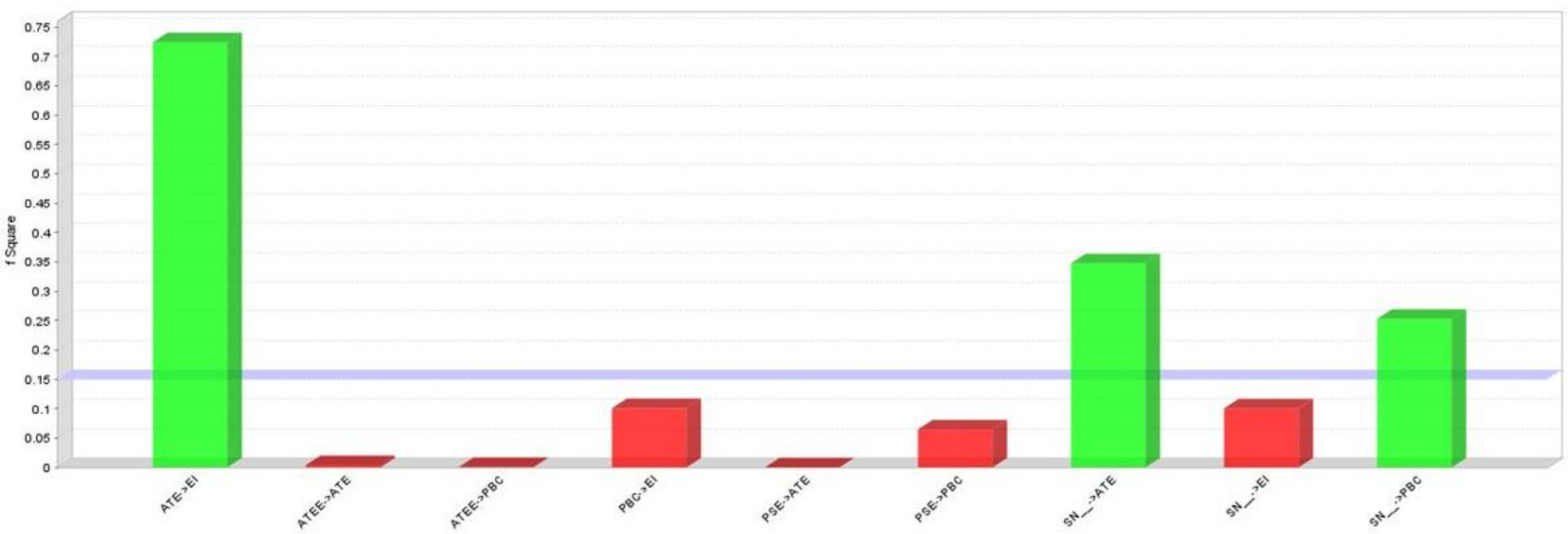

Figure 10

F Square

\section{Supplementary Files}

This is a list of supplementary files associated with this preprint. Click to download.

- FigA.JPG

- Appendix.docx 